\title{
Geology and genesis of vein-type corundum deposits in the Hafafit-Nugrus area, South Eastern Desert, Egypt
}

\author{
Soliman Abu Elatta A. Mahmoud*, Hani H. Ali \\ Nuclear Materials Authority, Cairo, Egypt \\ *corresponding author; e-mail: dr.soliman72@yahoo.com
}

\begin{abstract}
Unusual deposits formed by corundum are described from two separate pegmatitic veins in the Hafafit-Nugrus area of the South Eastern Desert of Egypt. Other related minerals are described too. The vein-type of corundum at Locality 1 (Vein 1) crosscuts through exposed rocks of an ophiolitic mélange, whereas at Locality 2 (Vein 2), it crosscuts through exposed serpentinised ultramafic rocks. The main minerals in Vein 1 are plagioclase, corundum, grossular, phlogopite, muscovite and clinochlore, while almandine, xenotime-(Y), allanite-(Ce), zircon, Cr-rich spinel, apatite, titanite, fergusonite-(Y), meta-ankoleite, U-rich thorite (uranothorite), carbonate and illite are the accessories. In Vein 2, the main minerals are plagioclase, corundum, phlogopite and chlorite, while clinochlore, euxenite- $(\mathrm{Y})$, Nb-rich rutile, almandine, xenotime-(Y), allanite-(Ce), zircon, spinel, apatite, titanite, kasolite, dickite, illite, carbonate, antigorite and talc are accessories. The two types of corundum veins differ in their concentrations of Th, $\mathrm{U}, \mathrm{Zr}, \mathrm{Nb}, \mathrm{Ta}, \mathrm{REE}, \mathrm{Y}$ and Li in wholerock compositions. Field observations, mineralogy and chemical analyses of samples from the two veins of corundum deposits, as well as concentrations of chromophore elements in corundum crystals, suggest metasomatic origins. The present study suggests that the two types of corundum veins formed at different ages from different residual magmas that underwent in-situ hybridisation with the host rocks.
\end{abstract}

Key words: Grossular, Cr-rich spinel, Nb-rich rutile, ultramafic rocks, secondary uranium minerals

\section{Introduction}

Of processes by which minerals (including corundum) form in nature, metasomatism is an important one. The process of metasomatism, as defined by the International Union of Geological Sciences (IUGS) on the Subcommission of Systematics of Metamorphic Rocks (SSMR), is a process by which the chemical composition of a rock or rock portion is altered in a pervasive manner, involving the introduction and/or removal of chemical components as a result of the interaction of the rock with aqueous fluids (solutions). Such processes take place when igneous intrusions emplaced into cool crustal rocks not only lose heat to cool surrounding rocks but also release reactive volatile components (Pirajno, 1992). Accordingly, deposits of minerals develop at the contacts between the cool crustal rocks composition of a magmatic body because of diffusive mass-transfer major rock-forming chemical components along their contact (e.g., Bucher et al., 2005). This metasomatic type is known as bimetasoma- 
tism (Zharikov et al., 2007), where both rocks are engaged in a two-way diffusion of different components across their contact.

Plumasite (Andrew Cowper, 1903) is a rock type that contains corundum and oilgoclase and is formed when a silica-bearing pegmatite intrudes into silica-deficient rocks. The silica is extracted from the pegmatite that interacts with silica-deficient host rocks or exchanged between the two. This produces new Si-enriched minerals in the host rocks, while fluid interacting with surrounding silica-deficient host rocks (e.g., mafic and ultramafic rocks) desilicifies the pegmatites.

Corundum in vein deposits is rare in the Migif-Hafafit area, which is a part of the Hafafit-Nugrus belt (El Ramly et al., 1993) in the South Eastern Desert of Egypt. Abu Elatta et al. (2013) recorded sapphire (blue, gem-quality) from the contact between peraluminous granites and metasedimentary host rocks at Madinat Nugrus, northeast of Gabal Hafafit. The corundum deposits were mined by Egypt's pharaohs to obtain abrasive materials (Serotta \& Carò, 2014).

The Hafafit-Nugrus area is one of the most spectacular Precambrian metamorphic complexes of the Arabian Nubian Shield (ANS) in the South Eastern Desert of Egypt (Fig. 1A). The metamorphic rocks in this area host economic mineral deposits (e.g., beryl, tourmaline, vermiculite, gold and feldspars). However, rock types, genesis, mineral associations, age and structural control of the corundum deposits in the Hafafit-Nugrus area are very constrained. The sole occurrence of corundum deposits in the Hafafit-Nugrus area in the Egyptian basement complex is puzzling. In order to solve this mystery, the present study tries to link the corundum deposits studied with the regional geological structures in the Hafafit-Nugrus area and the presence of residual melts from magmatic differentiation that favoured the formation of corundum deposits. To this end, twelve samples were collected from two types of corundum pegmatitic veins at different localities so as to carry out chemical analyses and mineralogical studies and to investigate concentrations of $U$, Th and other associated trace elements.

\section{Geological setting}

The Hafafit-Nugrus area is part of the Arabian-Nubian Shield that forms most of the basement rock units cropping out along the Red Sea in Egypt, Sudan, Ethiopia and Saudi Arabia. The upper Proterozoic basement was formed by accretion of ensimatic and ensialic arcs (Stoeser \& Camp, 1985) between
1,100-500 myr ago (Engel et al., 1980) as a sequential development from oceanic and island arc to a stable carton.

The Hafafit-Nugrus area is bounded to the northeast and northwest by metavolcanics, mica-schists and an ophiolitic mélange, to the west by the vast plain of gneissic granitoids which host a large number of dyke swarms of different ages, trachyte plugs (e.g., Gabal Hamrat Salma) and the Gabal Abu Khruq ring complex intrusion and to the south by the Wadi El Gemal thrust fault (Fig. 1B).

The rocks within the Hafafit-Nugrus area form two major groups based on metamorphic grade, complexity and deformations. These rocks are separated by a low angle (30-35 ) thrust fault and intruded by late Pan-African granitiods (El Ramly et al., 1993). They were formed during Pan-African convergent and marginal ocean basin processes. Elsewhere, there are Phanerozoic rocks (mostly difficult to map) and alluvium (El Ramly et al., 1984). Structurally, the upper group or the hanging wall of the Nugrus thrust fault includes low-grade mica-schists and metavolcanic units and is characterised by remnants of ophiolitic altered ultramafic rocks (serpentinites) and metagabbros. The lower group or the footwall of the Nugrus thrust fault consists of the Migif-Hafafit gneisses, which form the Hafafit domes. From north to south, these domes are labelled as A, B, C, D and E (El Ramly \& Greiling, 1988) (Fig. 1B) and comprise orthogneisses of tonalitic, trondhjemitic and granodioritic composition, banded amphibolites that were over-thrust by ultramafic rocks, alternating bands of biotiteand hornblende-gneisses and psammitic gneisses. In some parts, the amphibolite is associated with metagabbros (El Ramly \& Greiling, 1988).

The Phanerozoic rocks include basaltic-andesite, bostonite, trachyte dykes and plugs and acidic dykes. Although dykes trend in many directions, most of them have parallel ENE-WSW or NE-WS trends from Gabal Nugrus in the east to Gabal Abu Khruq in the west over a distance of more than 40 $\mathrm{km}$. The acidic dykes are the oldest and are cut by trachyte plugs (Abu Elatta, 2007), andesite, bostonite and trachyte dykes and syenite of the Abu Khruq ring complex (El Ramly et al., 1993; Abu Elatta, 2007), of presumably Late Cretaceous age (89 Ma; Serencsists et al., 1979). These rocks are younger than the post-Pan-African granites (595 Ma; Moghazi et al., 2004) and older than basic dykes. The basic and acidic dykes have an alkaline nature. In detail, trachyte dykes crosscut bostonite and andesite dykes and the latter are cut by the bostonite dyke. Trachyte plugs were dated as $80 \pm 9.8$ Ma (Stern, in Greiling et al., 1988). The deduced se- 
quence, with increasing age, is trachyte plugs, bostonite, trachyte dykes, basaltic andesite dykes and acidic dykes.

The ENE-WSW and NE-WS dykes may be emplaced largely along the chain of the great African faults, when their distribution pattern is compared with the regional tectonic structures which affected rocks in the south of Egypt, indicating the NE or ENE extension trends of the Chephren-Kom Ombo arch, one of three arches of the Trans-African shear zone (Pelusium megashear zone) that have affected Egypt (Issawi et al., 2009) since the Palaeozoic. The other two arches, the Tarfawi-Qena-South Sinai arch and the westerly Uweinat-Baharia-Port Said

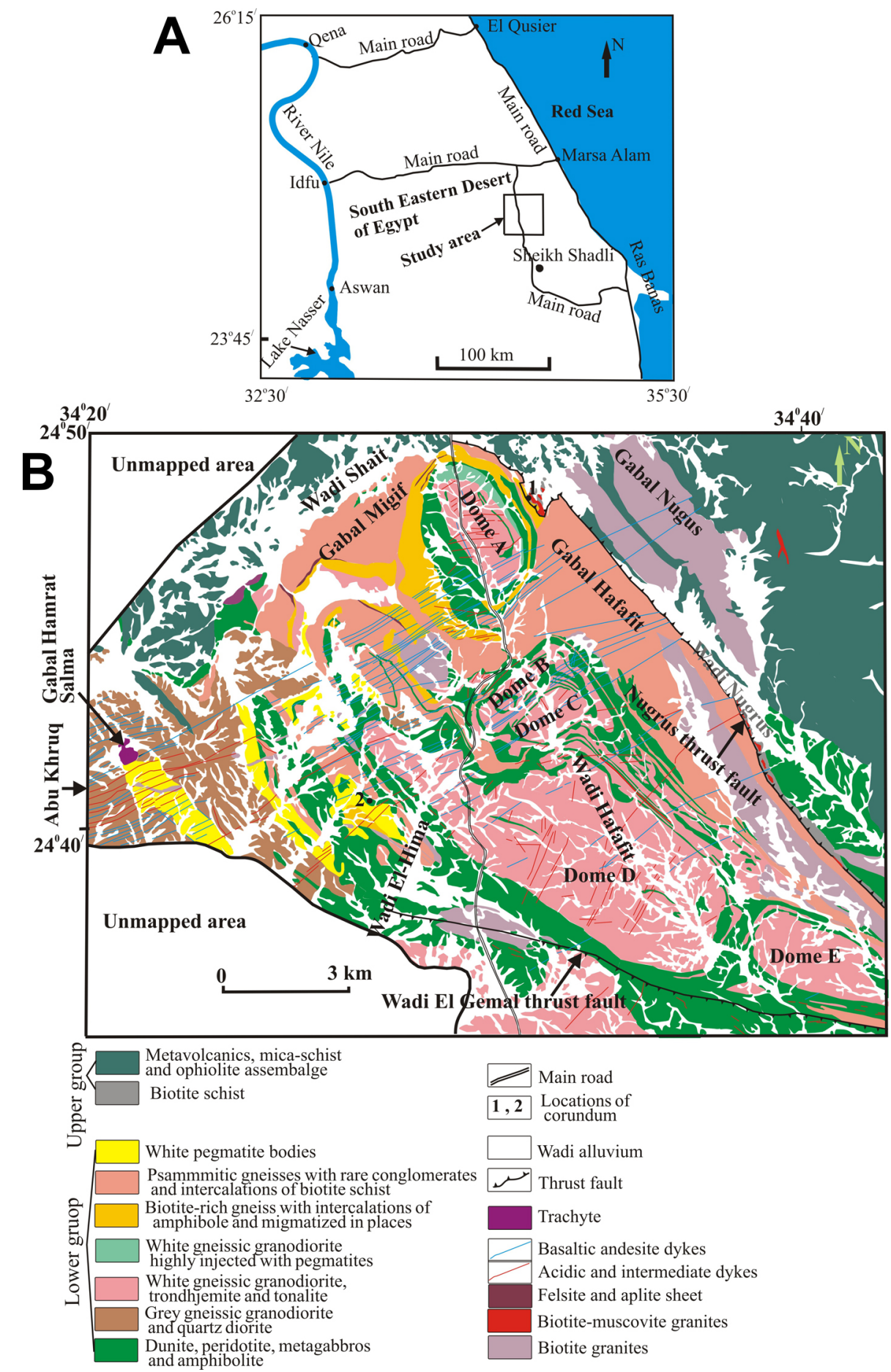

Fig. 1. A - Locality map of the Hafafit Nugrus area; B - Geological map of the Hafafit-Nugrus area (modified after El Ramly et al., 1993) 
arch, are situated west of this arch. The breakup of Gondwana and the early Central Atlantic opening during the Permo-Triassic led to reactivation of the arch structures and generation of alkaline magmas along them. The supporting evidence for this suggestion comes from numerous intermediate and acidic rocks formed during the Permo-Triassic time along these arches in the South Western Desert of Egypt, as the old eruptive pulse of the Nusab El Balgum complex (e.g., El Sayed et al., 2014; Abu Elatta \& Williams-Jones, 2018).

The Hafafit-Nugrus area shows the highest concentration of pegmatites in the Eastern Desert of Egypt. Those pegmatites form large bodies (extending for several kilometres with widths of up to $2 \mathrm{~km}$ ), while veins extend for over a kilometre with widths between $20 \mathrm{~cm}$ and $40 \mathrm{~m}$ and include lenses of white or red colour. These pegmatites have different ages and follow the regional structures of the area (El Ramly et al., 1993). Some pegmatites contain corundum, beryl, allanite and tourmaline (El Ramly et al., 1993).
Two types of corundum veins were studied from the Hafafit-Nugrus area after a spectrometry investigation for uranium anomalies associated with the igneous rocks. The two veins in separate host areas showed abnormal radioactive levels relative to the host rocks. The host rocks of Vein1 contain rock fragments of various sizes (serpentinites, metapyroxenites, metagabbros and metabasalts) in a matrix of metasedimentary rocks (biotite schist, actinolitic hornblende schist, metamudstone and graphite schist), biotite-muscovite granite and vermiculite. This vein is of small size (about $20 \mathrm{~cm}$ in width and $20 \mathrm{~m}$ in length) with a NNW-SSE strike and vertical dip (Fig. 2A). It cuts the ophiolitic mélange rocks and, towards to the southeast, disappears under serpentinite and metapyroxenite rock fragments. Vein 2 host rock units include pegmatites, serpentinised ultramafic rocks (Fig. 2B) and vermiculite enrichment, which occur as contact aureoles between the pegmatites and serpentinised ultramafic rocks. These vermiculite deposits represent the action of hydrothermal solutions on the remnant
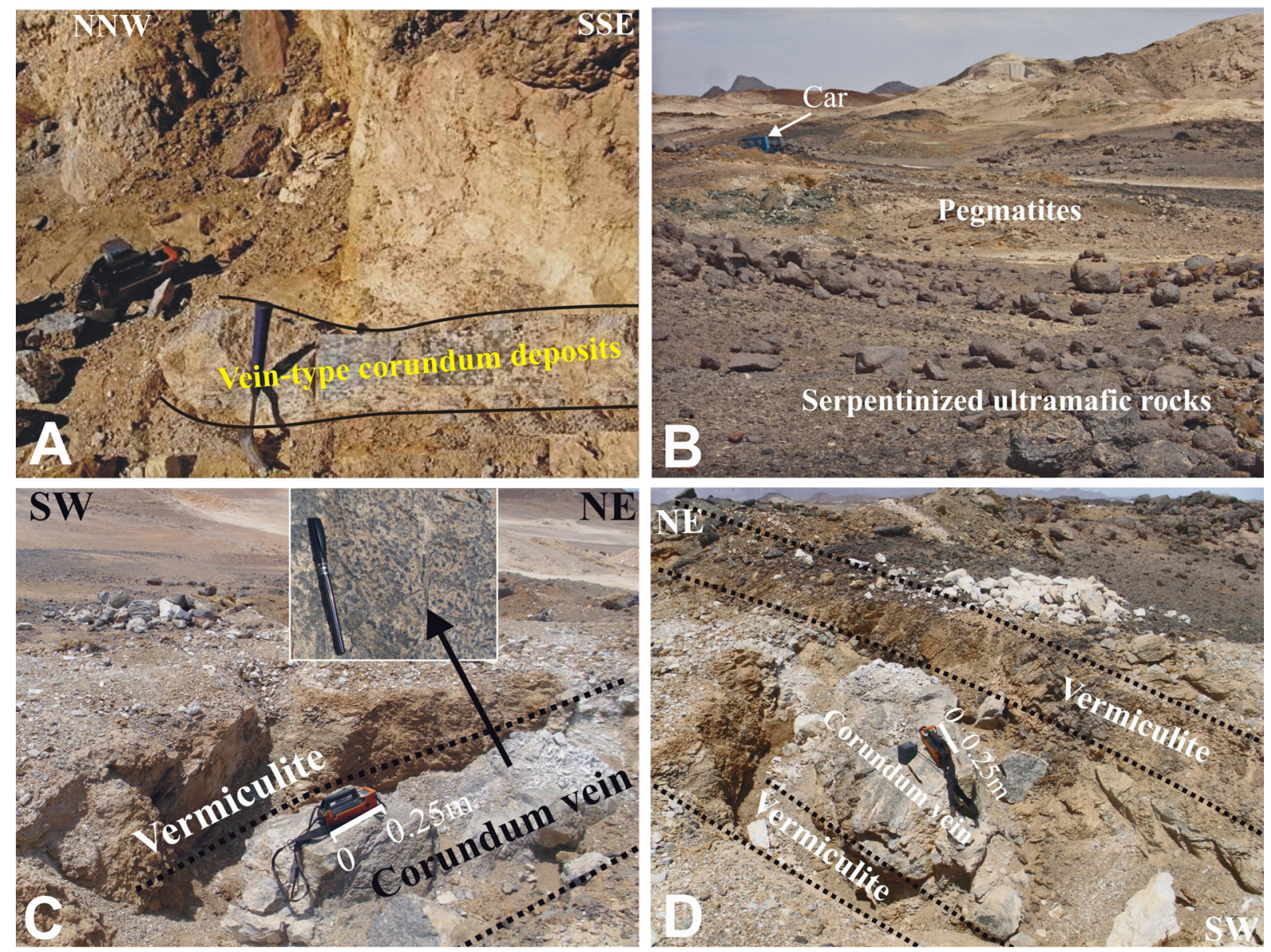

Fig. 2. Field photographs showing: A - vein-type of corundum deposits at locality 1; B -A general view of exposed rocks at locality 2; C - vein-type of corundum deposits, as well as vermiculite, at locality 2; D - vein-type of corundum deposits filling the NE-SW fracture 
masses of ultramafic rocks. The vein trends $33^{\circ} \mathrm{NE}$ (Fig. 2C), with a width of about $1 \mathrm{~m}$ and a length of $15 \mathrm{~m}$, and disappears to the east under serpentinised ultramafic rocks. It represents an injection of residual magma of an alkaline source rich in $\mathrm{Al}_{2} \mathrm{O}_{3}$ into a fracture that formed by older deformation processes (Fig. 2D).

\section{Laboratory methods}

For the petrographic study we used a Nikon (optical-pol) polarising microscope equipped with a full-automatic microphotography attachment (Micro flex AFX-II) at the Laboratory of Rock Studies of the Nuclear Materials Authority (Cairo, Egypt). An X-ray diffraction (XRD, Philips X-ray diffractometer, Model PW-105018) and the environmental scanning electron microscope (ESEM) coupled with energy dispersive spectroscopy (EDX, Philips, Model, XL30) was used for mineral identifications, particularly those that were difficult to identify by using the Nikon optical microscope. Selected samples of corundum vein deposits were crushed and sieved down to sizes between 0.25 and $0.843 \mathrm{~mm}$. The heavy mineral grains were separated by bromoform with a specific density of 2.8, washed with acetone and dried. In the concentrate, all heavy mineral grains were separated under a binocular microscope and then sent to XRD and ESEM/EDX
Laboratories at Nuclear Materials Authority (Cairo, Egypt).

Twelve representative samples (six from veintype 1 and six from vein-type 2 corundum deposits) were crushed down to a size of $0.074 \mathrm{~mm}$ and sent to the laboratories of ACME in Canada for determination of major oxides, trace and rare earth elements, using ICP-OES and ICP-MS methods.

Finally, six groups of corundum crystals of the two veins were separated by a binocular microscope according to the colour of the corundum crystals (three from Vein1 and three from Vein 2). They were crushed down to size of $0.074 \mathrm{~mm}$ and sent to the ICP-OES laboratory at the Survey and Mineral Resource Authority of Egypt to measure possible concentrations of chromophore and genetic indicator elements ( $\mathrm{Ti}, \mathrm{Fe}, \mathrm{Mg}, \mathrm{Ga}$ and $\mathrm{V}$ ).

\section{Results}

\subsection{Mineralogy}

The main rock-forming minerals in the corundum-bearing veins 1 and 2 are plagioclase, corundum, phlogopite and clinochlore, with grossular and muscovite in Vein 1. The mutual accessory minerals in the two veins are almandine, xenotime- $(\mathrm{Y})$, allanite-(Ce), zircon, spinel, apatite, illite and titanite. In addition, fergusonite-(Y), meta-ankoleite,

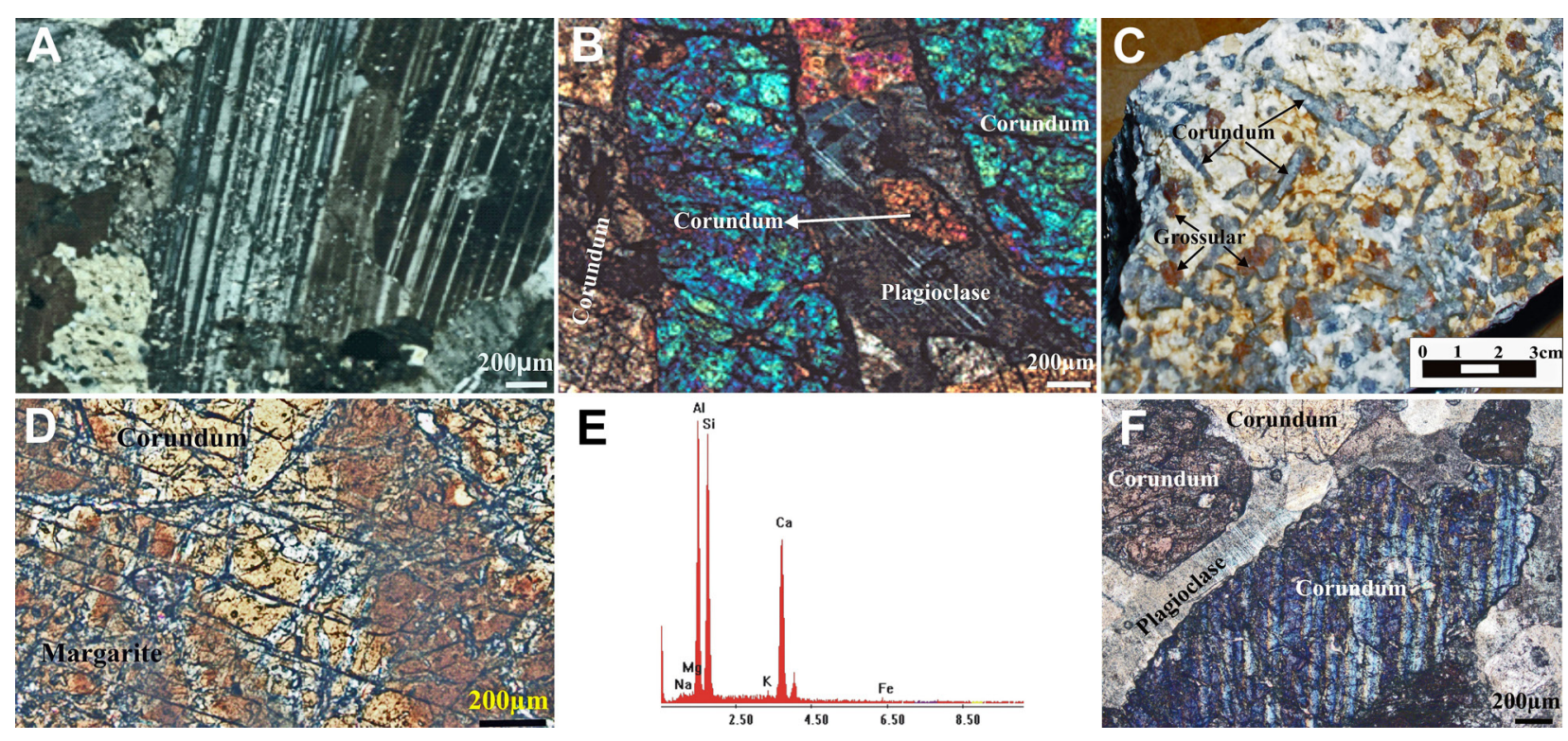

Fig. 3. General observations. A - Photomicrograph showing albite twinning in plagioclase (C.N.); B - Photomicrograph showing pericline twinning in plagioclase, which contains inclusions of corundum as well as prismatic crystals of corundum (C.N.); C - Field photograph showing megacrysts of corundum as well as grossular garnet from Vein 1; D - Megacryst of corundum, partially altered to margarite (R.L.); E -EDX pattern for pervious margarite; F - Photomicrograph showing lamellar twinning in corundum (C.N.). Abbreviations: R.L. - Reflected light, C.N. - Crossed nicols 


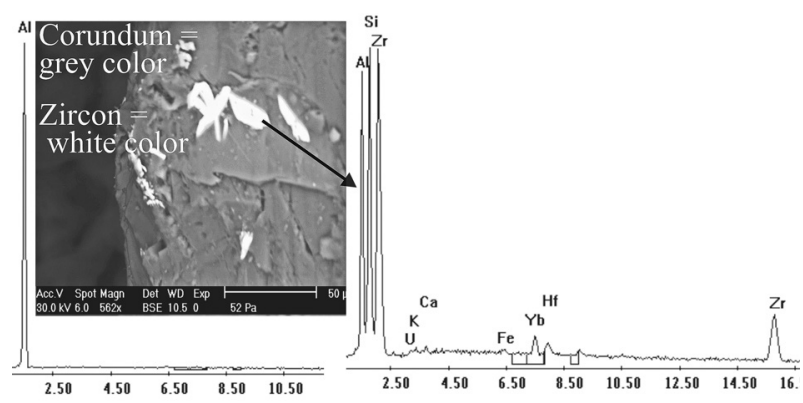

Fig. 4. ESEM image of corundum which contains inclusions of zircon and their EDX patterns

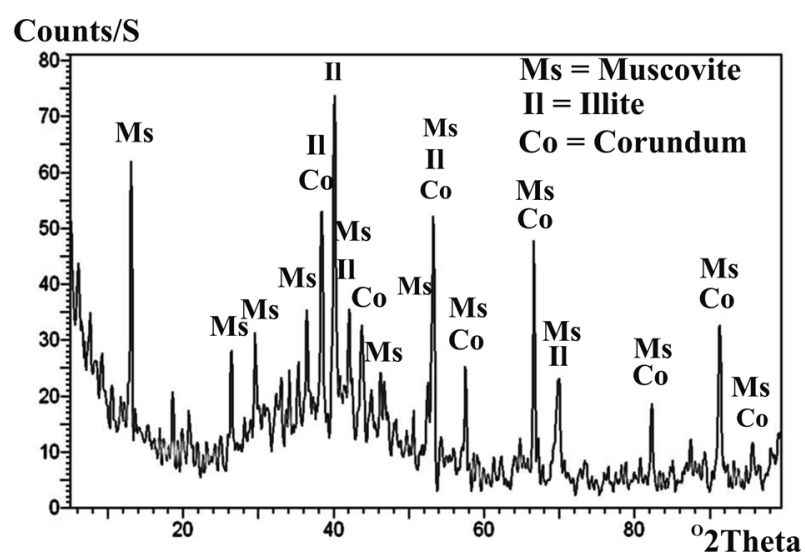

Fig. 5. XRD patterns for muscovite, illite and corundum

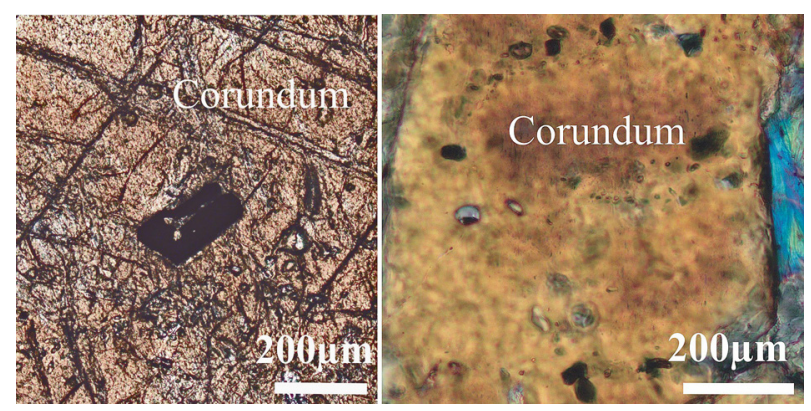

Fig. 6. Photomicrograph showing opaque inclusions in corundum crystals, as well as imperfect cleavages (crossed nicols)

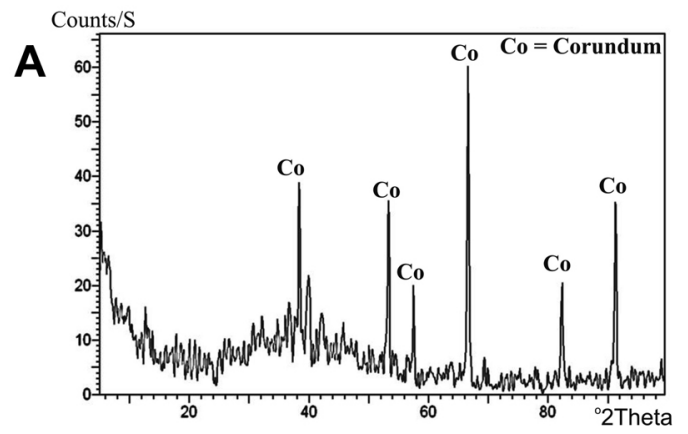

U-rich thorite and carbonate appear as accessories in Vein 1 samples, while kasolite, euxenite- $(\mathrm{Y}), \mathrm{Nb}$ rich-rutile, dickite, chlorite and talc appear in Vein 2 assemblages.

Plagioclase crystals $\left(\mathrm{An}_{45-20}\right)$ range in size from medium-grained (1-5 mm) to megacrysts (> $5 \mathrm{~mm}$ ). These crystals are white to whitish grey with anhedral to subhedral habits. They show albite (Fig. $3 \mathrm{~A})$ and pericline twinning (Fig. 3B). Plagioclase forms about $55 \mathrm{vol} \%$ of Vein 1 and about $60 \mathrm{vol} \%$ of the whole rock in Vein 2, where it is partially (Fig. 3A, B) to wholly altered and contains inclusions of idiomorphic corundum crystals (Fig. 3B). Corundum crystal sizes range from tiny (Fig. 3B) to megacrysts up to $3 \mathrm{~cm}$ in length and $0.4 \mathrm{~mm}$ in width (Fig. 3C). The mineral forms about $30 \mathrm{vol} \%$ of Vein 1 and about $35 \mathrm{vol} \%$ in Vein 2. The colour of corundum crystals varies from colourless, grey and pale purple in Vein 1 to pale green, grey, pale grey and pale yellow in Vein 2. Under the microscope, the corundum occurs as elongated euhedral to subhedral prismatic crystals. Some occasionally show spots of blue-sapphire or red-ruby varieties, an alteration to margarite (Figs. 3D, E), rather high relief, lamellar twins (Fig. 3F) and imperfect cleavages (Figs. 3D, 6). The crystals usually include zircon (Fig. 4), micas (Fig. 5) and opaque minerals (Fig. 6). Some corundum crystals from Vein 1 carry crystals of muscovite on the surface that is altered to illite (Fig. 5). Rare mica crystals are noted as inclusions in some crystals of corundum (Fig. 7A). Clinochlore $\left[\left(\mathrm{Mg}_{3} \mathrm{Fe}^{2+}\right)_{5} \mathrm{Al}_{2} \mathrm{Si}_{3} \mathrm{O}_{10}(\mathrm{OH})_{8}\right]$ occurs as yellow, green and black flakes. This mineral has been confirmed by XRD (Fig. 7B). It is commonly an indicator of hydrothermal environments and here usually accompanies antigorite (Fig. 8). Also, the previous figure showing clay and talc minerals replaced phlogopite. Grossular $\left(\mathrm{Ca}_{3} \mathrm{Al}_{2} \mathrm{Si}_{3} \mathrm{O}_{12}\right)$ occurs as pink subhedral to euhedral crystals, forming about 5 to 7 vol\% of Vein 1; it has been confirmed by XRD (Fig. 9A). It contains inclusions of zircon and U-rich thorite (Fig. 9B). U-rich thorite (uranoth-

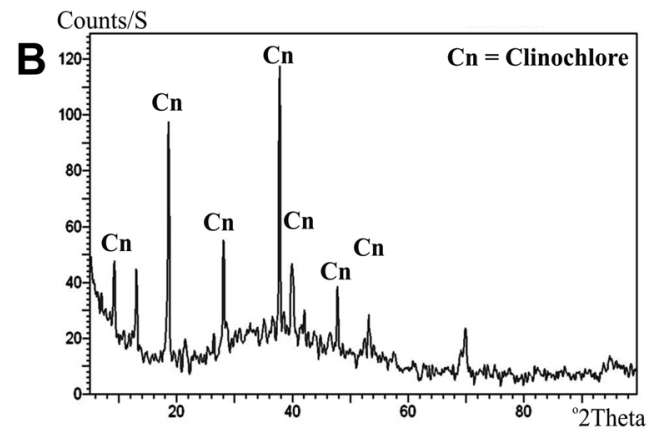

Fig. 7. A - XRD pattern of corundum; B - XRD pattern of clinochlore 


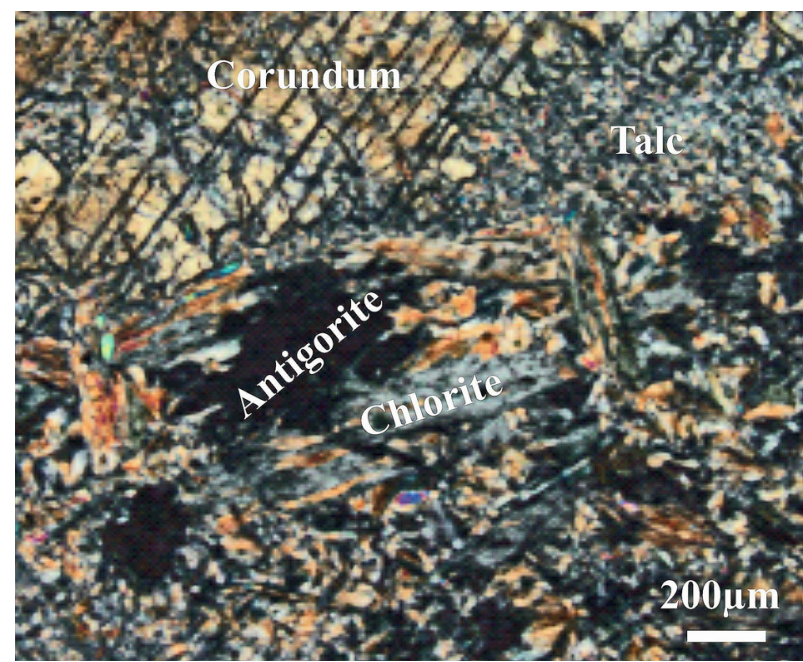

Fig. 8. Photomicrograph showing chlorite (including clinochlore), antigorite, corundum and talc (crossed nicols) orite) is here composed of $41.43 \% \mathrm{Th}, 12.2 \% \mathrm{U}$, and 11.28\% HREE and $8.12 \%$ Si. Considerable Ca and $\mathrm{Al}$ and minor $\mathrm{Mg}$ in the EDX result from the presence of grossular groundmass. Muscovite occurs as flakes or tiny shreds heterogeneously distributed throughout the rocks, but also on the surface or as inclusions of corundum crystals. The hydrothermal alteration of this mineral is represented by illite $(\mathrm{Al}, \mathrm{Mg}, \mathrm{Fe})_{2}(\mathrm{Si}, \mathrm{Al})_{4} \mathrm{O}_{10}\left[(\mathrm{OH})_{2},\left(\mathrm{H}_{2} \mathrm{O}\right)\right]$ that occurs as grey-white to silvery-white flakes.

Almandine $\left[\mathrm{Fe}_{3} \mathrm{Al}_{2}\left(\mathrm{SiO}_{4}\right)_{3}\right]$ is rare in the Vein 1 corundum deposits, compared to the Vein 2 deposits. Vein 1 almandine forms medium-sized, euhedral to subhedral crystals. The iron is partially replaced considerably by magnesium and manganese in some crystals. Some almandine crystals are transparent and constitute fine gemstones. Vein 2 almandine occurs as coarse dark red euhedral to
A
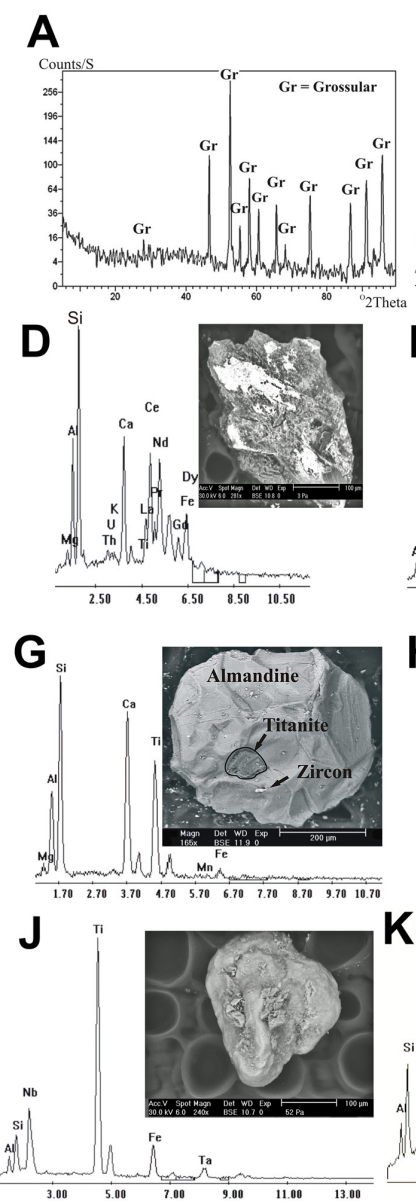
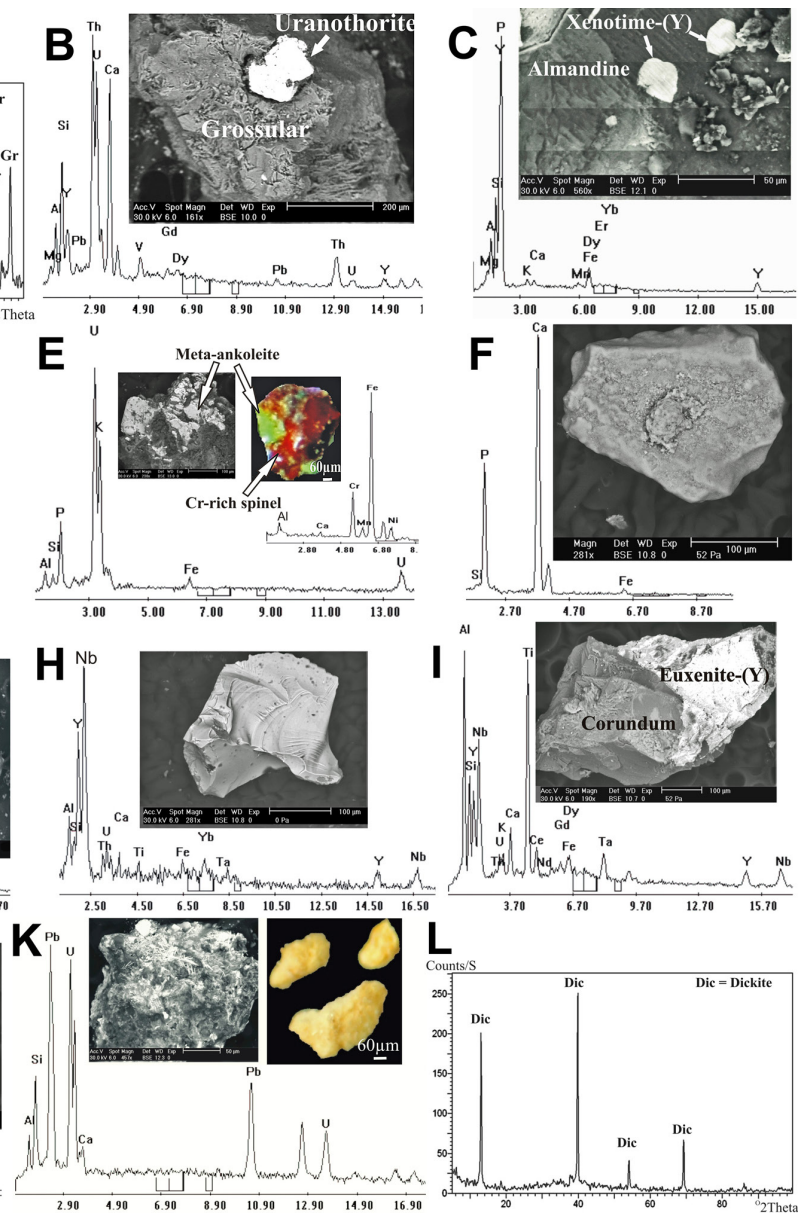

Fig. 9. A - XRD pattern of grossular; B - ESEM image of uranothorite as inclusion in grossular and EDX pattern for uranothorite; C - ESEM image of almandine containing inclusions of xenotime and EDX pattern of xenotime; D ESEM image and EDX pattern of allanite; E - Optical photograph showing meta-ankoleite on the surface of Cr-spinel and their ESEM image and EDX patterns; F - ESEM image and EDX pattern of apatite; G - ESEM image of almandine containing inclusions of titanite and zircon and EDX pattern of titanite; $\mathbf{H}$ - ESEM image and EDX pattern of fergusonite-(Y); I - ESEM image and EDX pattern of euxenite-(Y); J - ESEM image and EDX pattern of Nb-rich rutile; K - Optical photomicrograph and ESEM image and EDX pattern of kasolite; L - XRD pattern of dickite 
subhedral crystals. Almandine crystals from both veins contain inclusions of xenotime-( $\mathrm{Y})$ (Fig. 9C), titanite and zircon (Fig. 9G). Allanite-(Ce), [(Ca, Ce, $\left.\mathrm{La} . ..)_{2}(\mathrm{Al}, \mathrm{Fe})_{3}\left(\mathrm{SiO}_{4}\right)_{3}(\mathrm{OH})\right]$ occurs as reddish-brown tabular crystals. ESEM studies revealed the presence of $\mathrm{Nd}$ and $\mathrm{Gd}$ and minor $\mathrm{U}, \mathrm{Th}, \mathrm{Pr}$, Dy and $\mathrm{Mg}$ among its other constituents (Fig. 9D). Spinel $\left(\mathrm{MgAl}_{2} \mathrm{O}_{4}\right)$ is seen as colourless or dark green crystals under plane polarised light with a strong relief relative to surrounding minerals, but under reflected light, it shows an isotropic behaviour. Chrome-bearing spinel is recorded from Vein 1(Fig. 9E), where it results from the replacement of $\mathrm{Al}^{3+}$ by $\mathrm{Cr}^{3+}$ in the spinel structure. Apatite occurs as a yellow tabular crystals and examination by ESEM mainly recoded $\mathrm{Ca}$ and $\mathrm{P}$ elements and rare $\mathrm{Fe}$ (Fig. $9 \mathrm{~F})$. Titanite $\left(\mathrm{CaTiSiO}_{5}\right)$ is recorded only as an inclusion in non-gem almandine (Fig. 9G).

Fergusonite- $(\mathrm{Y}),\left[(\mathrm{Y}, \mathrm{REE}) \mathrm{NbO}_{4}\right]$ occurs as a honey-brown amorphous phase due to radiation damage. It was found by ESEM to be composed mainly of $46.58 \% \mathrm{Nb}, 23.14 \% \mathrm{Y}$ and $8.74 \% \mathrm{Yb}$ with greater Th and $\mathrm{U}$ content $(7.74 \%$ and $9.42 \%$, respectively for Th and $\mathrm{U}$ ) with $\mathrm{U}>\mathrm{Th}$ (Fig. 9H). Meta-ankoleite $\left[\mathrm{K}_{2}(\mathrm{UO})_{2}\left(\mathrm{PO}_{4}\right)_{2} \times 6 \mathrm{H}_{2} \mathrm{O}\right]$, a member of the meta-autunite group, occurs as green tabular and/or micaceous crystals. Normally yellow, the green colour of this mineral is due to its fluorescence in UV light. Meta-ankoleite was confirmed by ESEM/EDX (Fig. 9E) and is principally composed of $\mathrm{U}, \mathrm{P}$ and $\mathrm{K}$. The presence of $\mathrm{Al}$, Si in the EDX pattern represents contamination with clay minerals.

Euxenite- $(\mathrm{Y}),[(\mathrm{Y}, \mathrm{REE}>\mathrm{Ca}, \mathrm{U}, \mathrm{Th})(\mathrm{Nb}, \mathrm{Ta}$, $\mathrm{Ti}_{2} \mathrm{O}_{6}$ ] occurs as black prismatic crystals with pyramidal terminations. Euxenite- $(\mathrm{Y})$ was detected by ESEM (Fig. 9I) and has a composition of $22.46 \%$ $\mathrm{Y}+\mathrm{REE}, 4.76 \% \mathrm{U}, 1.54 \% \mathrm{Th}, 28.37 \% \mathrm{Nb}, 9.26 \% \mathrm{Ta}$, $13.22 \% \mathrm{Ti}$, and $2.38 \% \mathrm{Ca}$, with some impurities of $\mathrm{Al}, \mathrm{Si}, \mathrm{K}$ and $\mathrm{Fe}$ due to clay mineral contamination on the mineral surface. $\mathrm{Nb}$ rich-rutile occurs as black grains with submetallic luster. It was confirmed by ESEM (Fig. 9J) and is largely composed of Ti and Nb with impurities of $\mathrm{Al}, \mathrm{Si}$ and $\mathrm{Fe}$ due to clay minerals on its surface. The $\mathrm{Nb} / \mathrm{Ta}$ ratio $=2.46$ is typical of a hydrothermal origin. Kasolite $\left[\mathrm{Pb}\left(\mathrm{UO}_{2}\right) \mathrm{SiO}_{4} \times \mathrm{H}_{2} \mathrm{O}\right]$ occurs as an aggregate of reddish-orange fibres in Vein 2. It was confirmed by ESEM and is composed of $\mathrm{U}, \mathrm{Pb}$ and $\mathrm{Si}$ (Fig. 9K). The $\mathrm{Al}$ and $\mathrm{Ca}$ in the EDX pattern suggest contamination with clay minerals (Fig. 9K). Dickite $\left[\mathrm{Al}_{2} \mathrm{Si}_{2} \mathrm{O}_{5}(\mathrm{OH})\right]$, found only in Vein 2 as white to grey platelets, was confirmed by XRD (Fig. 9L).

\subsection{Geochemistry}

The analytical results of major oxides, trace element and rare earth element (REE) content of samples from Veins 1 and 2 are listed in Table 1. A comparison between the two veins shows that Vein 1 has higher $\mathrm{SiO}_{2}, \mathrm{CaO}, \mathrm{Na}_{2} \mathrm{O}$ and $\mathrm{Sr}$, whereas Vein 2 shows increased $\mathrm{Al}_{2} \mathrm{O}_{3}, \mathrm{FeOt}, \mathrm{MgO}, \mathrm{MnO}, \mathrm{K}_{2} \mathrm{O}, \mathrm{Li}$, $\mathrm{Ba}, \mathrm{Rb}, \mathrm{U}, \mathrm{Y}$ and HREE values. Moreover, the two veins have near-comparable average values of $\mathrm{P}_{2} \mathrm{O}_{5^{\prime}}$ $\mathrm{Ga}, \mathrm{Be}, \mathrm{Ta}, \mathrm{Hf}, \mathrm{Cr}$ and Th.

The binary diagram (Fig. 10A) shows an overall decrease in $\mathrm{SiO}_{2}$ with increasing $\mathrm{Al}_{2} \mathrm{O}_{3}$ (Fig. 10A), unlike the converse relationship between $\mathrm{MgO}$ and $\mathrm{Al}_{2} \mathrm{O}_{3}$ (Fig. 10B). Relationships between $\mathrm{CaO}$ and $\mathrm{SiO}_{2}$ are quite different with a slight increase in $\mathrm{CaO}$ with increasing $\mathrm{SiO}_{2}$ in Vein 1 (Fig. 10C), but a strong inverse relation in Vein 2 (Fig. 10C).

The chondrite-normalised REE patterns show for Vein 1 samples, HREE enrichment relative to LREE and (La/Yb) N ratio from 0.42 to 0.78 (average of 0.58), unlike Vein 2 samples that show inverse behaviour with LREE enrichment relative to HREE and (La/Yb)N ratio from 2.13 to 3.97 (average of 2.86). Samples from both veins, however, show Eu depletion and a slight positive Ce anomaly (Fig. 10D; Table 1).

The $\mathrm{Ce}$ and $\mathrm{Eu}$ anomalies depend on the elemental oxidation states in their environments, where mobility takes place under different oxidation-reduction conditions (Wang \& Liang, 2015). In oxidising environments with higher oxygen fugacity, $\mathrm{Ce}^{3+}$ is easily oxidised to $\mathrm{Ce}^{4+}$, which is much less mobile, thus producing a positive anomaly ( $\Delta$ $\mathrm{Ce}>1)$. Eu, conversely, in a reducing environment is compatible element in the divalent $\left(\mathrm{Eu}^{2+}\right)$ form, where it can substitute for $\mathrm{Ca}^{2+}$ in plagioclase and other calcium-bearing minerals, whereas in an oxidising environment it becomes an incompatible element in the trivalent $\left(\mathrm{Eu}^{3+}\right)$ form and is difficult to be incorporated into calcium-bearing minerals. Consequently, negative Eu anomalies in both vein samples studied indicate an oxidising environment.

\subsubsection{Hybridisation processes and fractionation indicators}

A very strong positive correlation between $U$ and Th exists in Vein 1 (Fig. 11A), in contrast to Vein 2. The Th/U ratio in Vein 1 ranges from 0.86 to 1.16 and from 0.26 to 0.61 in Vein 2. The ratio decreases strongly with increasing $\mathrm{SiO}_{2}$ in Vein 2, unlike a noticeable increasing trend of this ratio in Vein 1 (Fig. 11B). Such trends indicate fundamental genetic differences between the veins. 
Table 1. Major oxides (wt. \%), trace and rare earth elements (ppm), as well as some geochemical ratios for the two types of corundum vein studied herein

\begin{tabular}{|c|c|c|c|c|c|c|c|c|c|c|c|c|c|c|}
\hline \multirow{2}{*}{$\begin{array}{c}\text { Vein } \\
\text { Sample/ } \\
\text { Oxide }\end{array}$} & \multicolumn{7}{|c|}{1} & \multicolumn{7}{|c|}{2} \\
\hline & 1 & 2 & 3 & 4 & 5 & 6 & average & 7 & 8 & 9 & 10 & 11 & 12 & average \\
\hline $\mathrm{SiO}_{2}$ & 46.02 & 48.60 & 46.8 & 47.49 & 48.71 & 46.51 & 47.4 & 36.51 & 37.55 & 37.9 & 38.25 & 36.89 & 39.57 & 37.78 \\
\hline $\mathrm{TiO}_{2}$ & 0.8 & 0.6 & 0.69 & 0.7 & 0.7 & 0.7 & 0.7 & 0.9 & 0.83 & 0.65 & 0.8 & 0.6 & 0.8 & 0.79 \\
\hline $\mathrm{Al}_{2} \mathrm{O}_{3}$ & 33.56 & 32.60 & 33.2 & 32.9 & 32.40 & 33.21 & 32.98 & 43.01 & 42.2 & 41.89 & 41.60 & 42.85 & 41.65 & 42.2 \\
\hline $\mathrm{FeOt}$ & 4.16 & 3.09 & 3.7 & 3.69 & 3.78 & 3.64 & 3.677 & 3.74 & 4.79 & 5.43 & 6.43 & 6.51 & 5.03 & 5.32 \\
\hline $\mathrm{MgO}$ & 2.69 & 2.58 & 2.62 & 2.52 & 2.50 & 2.54 & 2.54 & 3.93 & 3.65 & 3.73 & 3.65 & 3.98 & 3.68 & 3.77 \\
\hline $\mathrm{CaO}$ & 7.87 & 7.97 & 7.93 & 7.57 & 7.70 & 7.55 & 7.77 & 4.62 & 3.98 & 3.73 & 3.72 & 4.56 & 3.63 & 4.04 \\
\hline $\mathrm{Na}_{2} \mathrm{O}$ & 2.33 & 2.60 & 2.45 & 2.58 & 2.36 & 2.71 & 2.51 & 0.68 & 0.91 & 1.13 & 1.09 & 1.10 & 1.19 & 1.02 \\
\hline $\mathrm{K}_{2} \mathrm{O}$ & 0.53 & 0.20 & 0.35 & 0.33 & 0.34 & 0.28 & 0.34 & 2.82 & 1.33 & 0.89 & 0.78 & 0.9 & 0.89 & 1.27 \\
\hline $\mathrm{P}_{2} \mathrm{O}_{5}$ & 0.08 & 0.03 & 0.06 & 0.024 & 0.03 & 0.02 & 0.04 & 0.05 & 0.05 & 0.04 & 0.04 & 0.03 & 0.02 & 0.04 \\
\hline $\mathrm{MnO}$ & 0.09 & 0.03 & 0.05 & 0.055 & 0.08 & 0.04 & 0.06 & 0.44 & 0.45 & 0.32 & 0.43 & 0.23 & 0.36 & 0.37 \\
\hline L.O.I & 2.40 & 2.35 & 2.24 & 2.5 & 2.10 & 2.95 & 2.242 & 2.97 & 3.32 & 3.35 & 3.10 & 2.73 & 3.11 & 3.1 \\
\hline Total & 100.5 & 100.1 & 100.1 & 100.4 & 100.0 & 100.1 & 100.3 & 99.67 & 99.15 & 99.06 & 99.89 & 100.4 & 99.93 & 99.7 \\
\hline \multicolumn{15}{|c|}{ Trace elements } \\
\hline $\mathrm{Li}$ & 38.4 & 33.9 & 35.5 & 43.6 & 48.7 & 41.7 & 40.3 & 52.2 & 223 & 173 & 323.7 & 111.7 & 335.7 & 203.22 \\
\hline Cs & 2.9 & 2.4 & 2.6 & 2.5 & 2.6 & 2.3 & 2.55 & 2.8 & 5.7 & 7.3 & 9.6 & 5.5 & 12.0 & 7.15 \\
\hline $\mathrm{Ba}$ & 454 & 386 & 434 & 364 & 363 & 367 & 394.67 & 886 & 611 & 325 & 526 & 263 & 553 & 527.33 \\
\hline $\mathrm{Sr}$ & 658 & 703 & 658 & 590 & 627 & 587 & 637.17 & 481 & 375 & 334 & 361 & 383 & 309 & 373.83 \\
\hline $\mathrm{Ga}$ & 24.66 & 17.66 & 18.48 & 17.67 & 17.22 & 18.8 & 19.08 & 24.10 & 22.5 & 22.5 & 22.22 & 24.39 & 21.39 & 22.85 \\
\hline Hf & 6.61 & 5.88 & 6.32 & 7.5 & 9.99 & 6.02 & 7.05 & 8.32 & 8.5 & 8.43 & 9.05 & 9.24 & 6.1 & 8.64 \\
\hline $\mathrm{Be}$ & 10.00 & 8.00 & 8.5 & 7 & 7.00 & 7.00 & 7.92 & 13.00 & 5.5 & 2.31 & 2.00 & 3.00 & 2.00 & 4.64 \\
\hline $\mathrm{Ta}$ & 12.80 & 12.20 & 11.89 & 17.35 & 20.50 & 12.20 & 14.47 & 29.40 & 13.5 & 5.00 & 7.00 & 5.00 & 6.10 & 11 \\
\hline $\mathrm{Cr}$ & 125 & 90 & 110.5 & 62.25 & 4 & & & & & & 59 & & 51 & 65.67 \\
\hline $\mathrm{Rb}$ & 49.3 & 39.8 & 43.25 & 41.93 & 42.7 & 41.5 & 43.08 & 140.5 & 92.5 & 69.5 & 83.5 & 29.5 & 104.1 & 86.6 \\
\hline $\mathrm{Nb}$ & 39.00 & 40.97 & 40.25 & 59.4 & 70.99 & 40.42 & 48 & 102.2 & 40.23 & 9.5 & 13.38 & 7.54 & 11.34 & 30.7 \\
\hline $\mathrm{Zr}$ & 78.00 & 72.90 & 74.5 & 90.59 & 160.4 & & & & 122 & 90.25 & 136.8 & 130.4 & 25.80 & 103.36 \\
\hline $\mathrm{U}$ & 42.3 & 35.2 & 39.2 & 43.3 & 50.8 & 31.7 & 40.42 & 107.2 & 107.6 & 99 & 108.9 & 89.7 & 103.9 & 102.72 \\
\hline Th & 36.4 & 40.8 & 38.96 & 41.2 & 50.8 & 29.1 & 39.54 & 65.8 & 51.3 & 40.4 & 28.5 & 42.8 & 31.7 & 43.42 \\
\hline \multicolumn{15}{|c|}{ REE } \\
\hline $\mathrm{La}$ & 22.10 & 21.30 & 17.5 & 17.0 & 22.70 & 13.50 & 19.02 & 57.00 & 13.5 & 8.0 & 6.8 & 15.60 & 6.00 & 17.82 \\
\hline $\mathrm{Ce}$ & 4.09 & 53.36 & 42.40 & 39.4 & 55.77 & 33.25 & 38.05 & 136.7 & 33.5 & 19.5 & 17.01 & 41.28 & 15.05 & 43.83 \\
\hline $\operatorname{Pr}$ & 7.30 & 7.40 & 5.3 & 4.9 & & & & & & 2.7 & & & 2.10 & \\
\hline $\mathrm{Nd}$ & 30.80 & 30.70 & 24.5 & 21.9 & 30.50 & 18.70 & 26.18 & 77.40 & 24.5 & 10.5 & 10.40 & 28.00 & 9.60 & 26.73 \\
\hline $\mathrm{Sm}$ & 12.40 & 11.80 & 17.9 & 8.9 & 11.20 & 7.40 & 116 & 35.40 & 10.6 & 5.2 & 4.80 & 12.80 & 4.30 & 12.18 \\
\hline $\mathrm{Eu}$ & 0.60 & 0.60 & 0.6 & 0.5 & 0.60 & 0.50 & 7 & 0.90 & 0.6 & 0.6 & 0.50 & 0.60 & 0.40 & 0.6 \\
\hline $\mathrm{Gd}$ & 18.30 & 17.20 & 17.6 & 12.9 & 14.40 & 12.70 & 15.52 & 42.60 & 13.7 & 5.5 & 5.90 & 16.40 & 5.20 & 14.88 \\
\hline $\mathrm{Tb}$ & 4.70 & 4.30 & 4.4 & 3.5 & 3.30 & 3.50 & 3.95 & 7.20 & 2.36 & 1.0 & 1.00 & 2.50 & 0.90 & 2.49 \\
\hline Dy & 34.60 & 31.40 & 32.0 & 24.4 & 24.00 & 26.20 & 28.77 & 33.50 & 10.2 & 5.4 & 5.70 & 12.50 & 5.30 & 12.1 \\
\hline Ho & 6.60 & 6.30 & 6.5 & 4.8 & 4.90 & 5.40 & 5.75 & 4.60 & 1.68 & 1.0 & 0.80 & 1.80 & 0.90 & 1.8 \\
\hline Er & 20.20 & 20.50 & 20.2 & 17.0 & 16.60 & 17.40 & 18.65 & 11.30 & 3.1 & 2.4 & 2.20 & 3.60 & 2.0 & 4.1 \\
\hline $\mathrm{Tm}$ & 3.20 & 3.30 & 3.2 & 2.6 & 2.70 & & & & 0.4 & 0.3 & 0.30 & 0.50 & 0.32 & 0.54 \\
\hline $\mathrm{Yb}$ & 23.40 & 23.70 & 23.8 & 20.8 & 19.50 & 21.50 & 22.12 & 21.60 & 2.4 & 2.1 & 10.20 & 3.1 & 1.9 & 6.88 \\
\hline $\mathrm{Lu}$ & 3.10 & 2.80 & 3.3 & 2.6 & 3.00 & 1.20 & 2.67 & 1.20 & 0.31 & 0.3 & 0.30 & 0.43 & 0.3 & 0.47 \\
\hline Y & 195.9 & 193.0 & 190.7 & 145.6 & 139.5 & 159.10 & 170.64 & 122.0 & 35.3 & 23.5 & 21.70 & 30.70 & 21.10 & 42.38 \\
\hline$\sum$ LRRE & 77.29 & 125.2 & 108.2 & 92.6 & 128.1 & 77.55 & 101.48 & 326 & 87.2 & 46.5 & 41.81 & 104.2 & 37.45 & 107.19 \\
\hline$\sum$ HREE & 114.1 & 109.5 & 111 & 88.6 & 88.4 & 90.9 & 100.42 & 123.4 & 34.15 & 18 & 26.4 & 40.83 & 16.82 & 43.27 \\
\hline$\sum$ REE & 191.4 & 234.7 & 219.2 & 181.2 & 216.5 & 168.4 & 201.9 & 449.4 & 121.3 & 64.5 & 68.21 & 145.0 & 54.27 & 150.46 \\
\hline$R E E+Y$ & 387.3 & 427.7 & 409.9 & 326.8 & 356 & 327.5 & 327.55 & 571.4 & 156.6 & 88 & 89.91 & 175.7 & 75.37 & 192.84 \\
\hline$\Delta \mathrm{Eu}$ & 0.12 & 0.13 & 0.13 & 0.14 & 0.14 & 0.16 & 0.14 & 0.07 & 0.15 & 0.34 & 0.29 & 0.13 & 0.26 & 0.19 \\
\hline$\Delta \mathrm{Ce}$ & 1.02 & 1.02 & 1.05 & 1.03 & 1.03 & 1.06 & 1.04 & 1.01 & 1.03 & 1.03 & 1.03 & 103 & 1.02 & 1.03 \\
\hline$(\mathrm{La} / \mathrm{Yb}) \mathrm{N}$ & 0.64 & 0.61 & 0.5 & 0.55 & 0.78 & 0.42 & 0.58 & 3.77 & 3.97 & 2.57 & 2.41 & 2.29 & 2.13 & 32.86 \\
\hline $\mathrm{Th} / \mathrm{U}$ & 0.86 & 1.16 & 0.99 & 0.95 & 1 & 0.91 & 0.98 & 0.61 & 0.48 & 0.41 & 0.26 & 0.48 & 0.31 & 0.43 \\
\hline $\mathrm{Nb} / \mathrm{Ta}$ & 3.05 & 3.36 & 3.38 & 3.42 & 3.43 & 3.31 & 3.33 & 3.47 & 2.98 & 1.9 & 1.91 & 1.51 & 1.86 & 2.27 \\
\hline $\mathrm{Zr} / \mathrm{Hf}$ & 11.8 & 12.4 & 11.79 & 12.08 & 16.06 & 12.52 & 12.78 & 13.81 & 14.35 & 10.7 & 15.11 & 14.11 & 4.23 & 12.1 \\
\hline
\end{tabular}

$\mathrm{FeOt}=$ total iron. 
Lentz (1996) reported that the hybridisation index of $\mathrm{FeOt}+\mathrm{MgO}+\mathrm{CaO}$ was useful in quantifying deviations from leucogranite melt compositions. Figure $11 \mathrm{C}$ indicates a lack of correlation for Vein 1, while a significant correlation with $\mathrm{Zr}$ exists in
Vein 2. The samples of the two veins show a weak correlation between Th and the hybridisation index (Fig. 11D), whereas U shows a positive weak relationship to the hybridisation index in Vein 1, but a strong inverse one in Vein 2 (Fig. 11E). The hybrid-
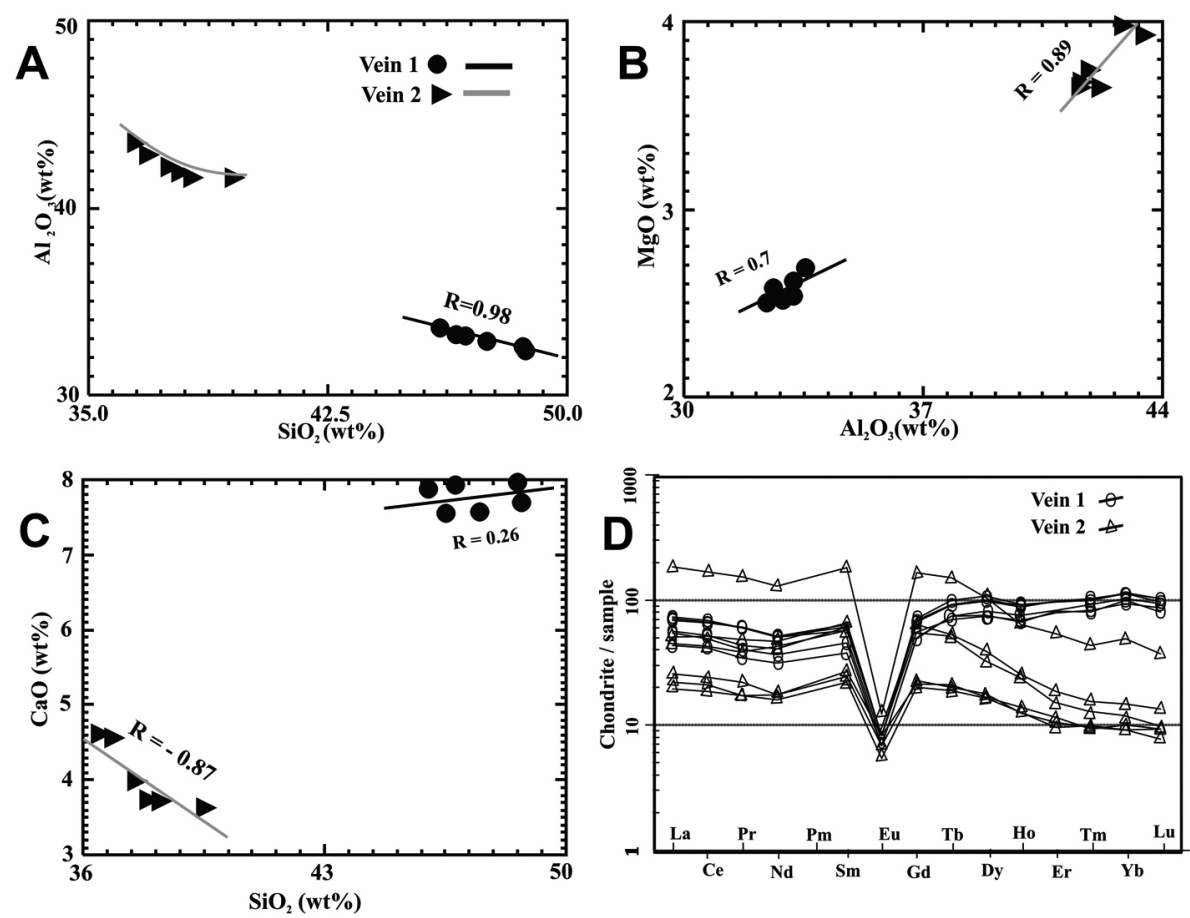

Fig. 10. Diagrams of the two vein types of corundum deposits studied. A - $\mathrm{SiO}_{2}(\mathrm{wt} \%)$ vs $\mathrm{Al}_{2} \mathrm{O}_{3}$ (wt \%); $\mathbf{B}-\mathrm{Al}_{2} \mathrm{O}_{3}(\mathrm{wt} \%$ ) vs $\mathrm{MgO}$ (wt \%); C - $\mathrm{SiO}_{2}$ (wt \%) vs $\mathrm{CaO}$ (wt \%); D - Chondrite normalised REE patterns (Boynton, 1984)
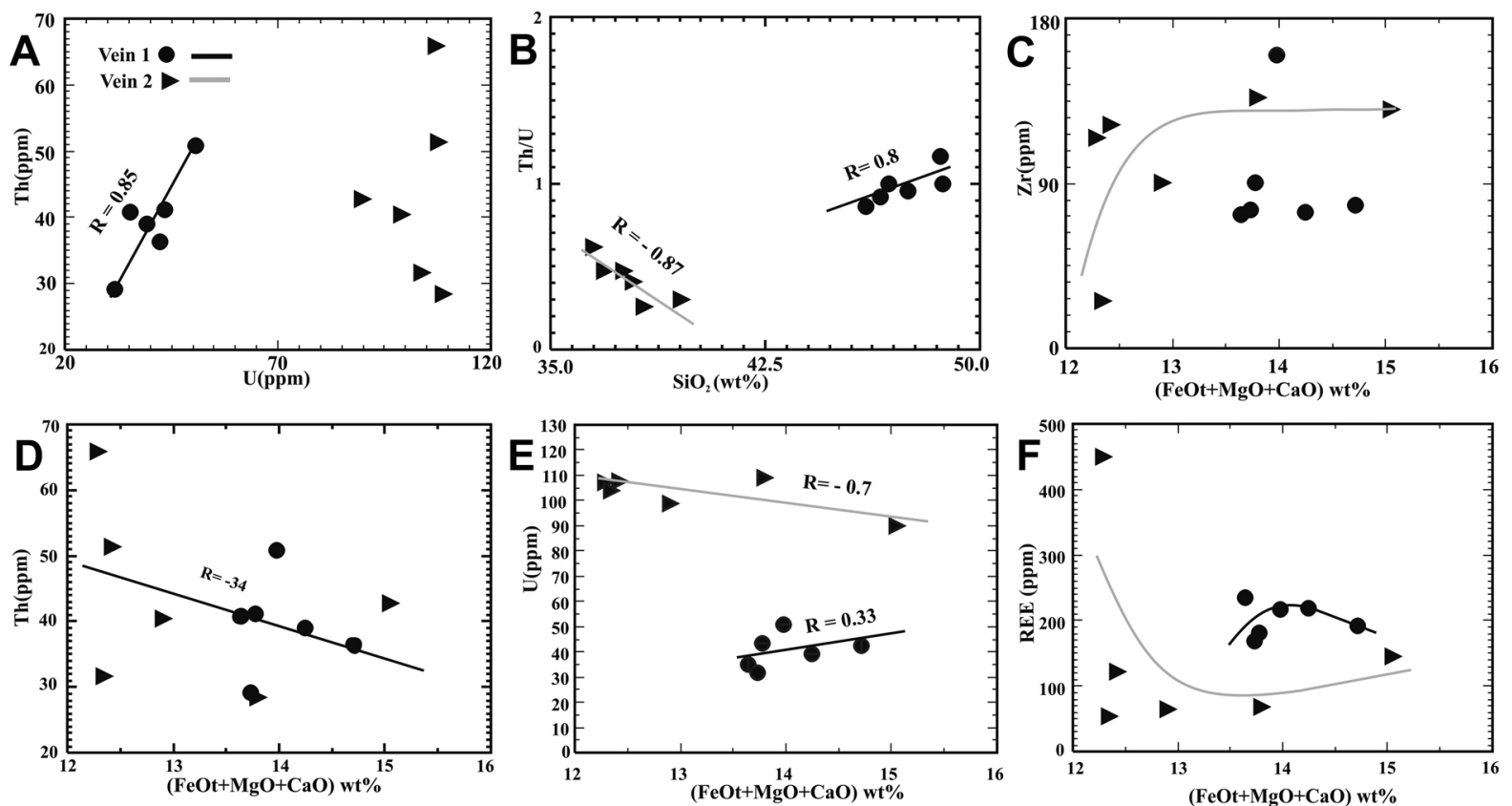

Fig. 11. A - Diagram of U (ppm) vs Th (ppm); B - $\mathrm{SiO}_{2}(\mathrm{wt} \%)$ vs Th/U; C - (FeOt+MgO+CaO) wt $\%$ vs $\mathrm{Zr}$ (ppm); D $(\mathrm{FeOt}+\mathrm{MgO}+\mathrm{CaO}) \mathrm{wt} \%$ vs Th $(\mathrm{ppm}) ; \mathbf{E}-(\mathrm{FeOt}+\mathrm{MgO}+\mathrm{CaO}) \mathrm{wt} \%$ vs $\mathrm{U}(\mathrm{ppm}) ; \mathbf{F}-(\mathrm{FeOt}+\mathrm{MgO}+\mathrm{CaO}) \mathrm{wt} \%$ vs $\mathrm{REE}$ (ppm) 

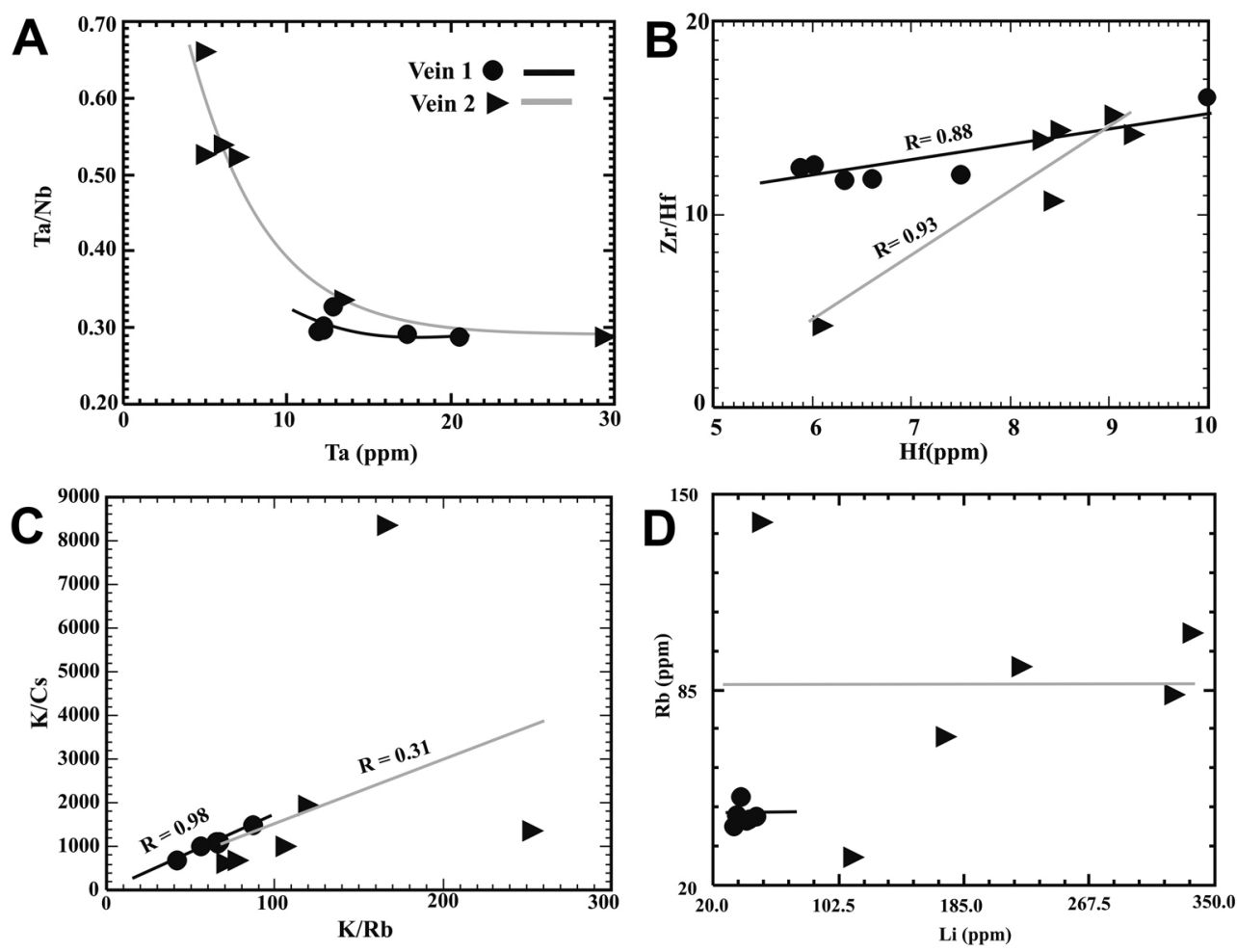

Fig. 12. A - Diagram of Ta (ppm) vs Ta/Nb; B - Zr vs Zr/Hf ratios; C - K/Rb vs K/Cs; D - Rb vs Li

isation index, however, shows a significant correlation with the total REE concentrations for samples of both veins (Fig. 11F).

The $\mathrm{Nb}$-Ta and Zr-Hf paired elements are very close in geochemical relationships due to their separation by lanthanide contraction. They display a fractionation pattern opposite to that expected from ionic properties (Černý et al., 1985). The Nb/Ta ratios of primitive mantle melts are rather constant with values of $17.5 \pm 2$ (e.g., Green, 1995), whereas these ratios for bulk continental crust range from 11 to 12 (Taylor \& McLennan, 1985; Rudnick \& Fountain, 1995). This indicates that these two elements were fractionated from each other in the continental crust (e.g., Linnen \& Keppler, 2002). A Nb/ Ta $\leq 3.42$ for the samples studied (Table 1) would be a proxy for hydrothermal processes (Ballouard et al., 2016). The samples studied show obvious fractionation trends when their Ta values are compared with the $\mathrm{Ta} / \mathrm{Nb}$ ratios (Fig. 12A).

The $\mathrm{Zr} / \mathrm{Hf}$ ratio in many granites is about 39 ( $n=327$; Erlank et al., 1978), near to the chondritic ratio of 38 (Anders \& Grevesse, 1989). The $\mathrm{Zr} / \mathrm{Hf}$ ratio in granites strongly affected by magmatic hydrothermally alterations is less than 20 (Irber, 1999). The average $\mathrm{Zr} / \mathrm{Hf}$ in pegmatites is about 25 ( $\mathrm{n}=$ 107; Erlank et al., 1978) and shifts towards smaller ratios with increasing evolution of the silicate melt (Weyer et al., 2002). The $\mathrm{Zr} / \mathrm{Hf}$ ratio in samples from Vein 1 ranges from 11.79 to 16.06 with an average of 12.78, whereas samples from Vein 2 differed in range from 4.23 to 15.11 with an average of 12.1. The plot of the Hf values vs the $\mathrm{Zr} / \mathrm{Hf}$ ratios for the two vein types shows strong positive correlations (Fig. 12B). Similarly, plots of K/Rb vs K/Cs for the two veins studied show positive linear correlations (Fig. 12C). Plots of $\mathrm{Rb}$ vs Li reveal that $\mathrm{Rb}$ values remain steady with increasing Li (Fig. 12D).

\subsection{Genesis}

Chromophore elements such as $\mathrm{Mg}$, Fe, Ti, Cr, V and a genetic indicator element $\mathrm{Ga}$ (Table 2) have been used by many authors (e.g., Rankin et al., 2003; Peucat et al., 2007; Voudouris et al., 2019) to distinguish between magma-sourced and a variety of metamorphic or metasomatic crystallised corundum. Such a study relies on discernible variations in elemental concentrations in relation to such source rocks (e.g., Saminpanya et al., 2003; Abduriyim \& Kitawaki, 2006; Peucat et al., 2007). According to Peucat et al. (2007), the Fe-Mg*100-Ti*10 ternary plot can be used to distinguish between magmatic and metamorphic corundum varieties. The magmatic corundum plots along the upper Fe-Ti side, whereas the metamorphic and metasomatic corundum varieties are scattered along the lower $\mathrm{Mg}$-Ti side. The an- 

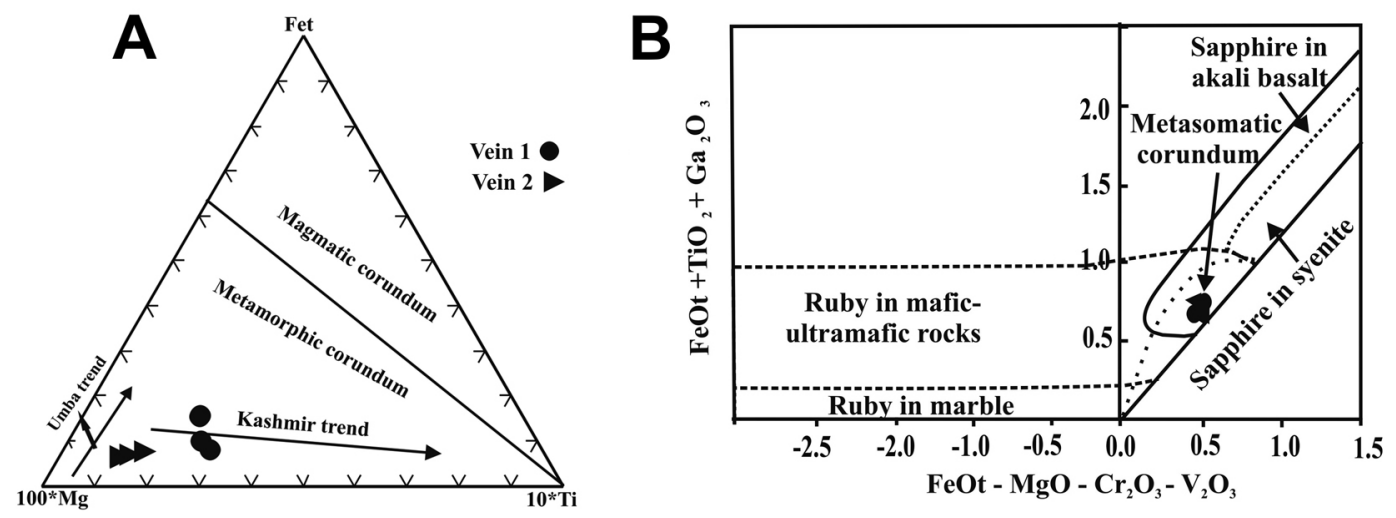

Fig. 13. A - Mg*100-Ti*10-Fetternary diagram; B - $\left[\mathrm{FeOt}-\left(\mathrm{MgO}+\mathrm{Cr}_{2} \mathrm{O}_{5}+\mathrm{V}_{2} \mathrm{O}_{5}\right) w \mathrm{t} \%\right.$ vs $\left(\mathrm{FeOt}+\mathrm{TiO}_{2}+\mathrm{Ga}_{2} \mathrm{O}_{3}\right) \mathrm{wt} \%$ for corundum deposits studied

Table 2. Concentrations of chromophore elements in corundum crystals.

\begin{tabular}{|cccccccc|}
\hline Vein & & 1 & & & 2 & \\
\hline Sample no. & 1 & 2 & 3 & 4 & 5 & 0.1 \\
\hline $\mathrm{TiO}_{2}$ wt $\%$ & 0.183 & 0.08 & 0.13 & 0.12 & 0.09 & 0.060 \\
$\mathrm{MgO}$ wt $\%$ & 0.041 & 0.022 & 0.033 & 0.058 & 0.062 & 0.55 \\
\hline $\mathrm{FeOt}$ wt $\%$ & 0.52 & 0.57 & 0.51 & 0.6 & 0.57 & 6 & 7 \\
$\mathrm{Cr}(\mathrm{ppm})$ & 8 & 5 & 6 & 1 & 1 & UD \\
$\mathrm{V}(\mathrm{ppm})$ & 1 & 1 & 1 & $\mathrm{UD}$ & $\mathrm{UD}$ \\
$\mathrm{Ga}(\mathrm{ppm})$ & $\mathrm{UD}$ & $\mathrm{UD}$ & $\mathrm{UD}$ & & & \\
\hline
\end{tabular}

$\mathrm{UD}=$ under detection limit.

alytical plots of corundum samples from the two veins are distributed along the Mg-Ti compositional side, indicating a metamorphic/metasomatic origin (Fig. 13A). Using the FeOt- $\mathrm{Cr}_{2} \mathrm{O}_{3}-\mathrm{MgO}-\mathrm{V}_{2} \mathrm{O}_{3}$ vs Fe$\mathrm{Ot}+\mathrm{TiO}_{2}+\mathrm{Ga}_{2} \mathrm{O}_{3}$ discrimination diagram (Fig. 13B) to distinguish between corundum from different sources like mafic-ultramafic rocks, marble, basalt, syenite and metasomatic rock types, all samples fell within the field assigned to metasomatic sapphires. Consequently, the studied corundum deposits formed from pegmatitic melts that were subjected to metasomatic processes.

\section{Discussion}

The studied corundum occurrences are emplaced in two separate pegmatitic veins in the Hafafit-Nugrus and formed by juxtaposition of hot residual melts and cool silica-deficient rocks. The hot residual melts were rich in $\mathrm{SiO}_{2}, \mathrm{Al}_{2} \mathrm{O}_{3}$ and other elements, while cool silica-deficient rocks were the ophiolitic mélange fragments of various sizes (serpentinites, metapyroxenites, metagabbros and metabasalts) in a matrix of metasedimentary rocks (biotite schist, actinolitic hornblende schist, metamudstone and graphite schist and serpentinised ultramafic rocks for Vein 1 at locality 1 and serpentinised ultramafic rocks for Vein 2. Consequently, the resulting intense contact bimetasomatic activity was characterised by an elemental exchange, where $\mathrm{SiO}_{2}, \mathrm{Li}, \mathrm{Nb}, \mathrm{U}, \mathrm{Th}$, and the most of $\mathrm{H}_{2} \mathrm{O}$, REE and $\mathrm{Y}$ would be offered by hot residual melts (pegmatitic melts), while the majority of $\mathrm{MgO}$, FeOt and $\mathrm{CaO}$ were supplied by the ophiolitic mélange and serpentiniszed ultramafic rocks (Fig. 14). In addition, a little of REE and U would be offered by the ophiolitic mélange rocks. Thus, the $\mathrm{SiO}_{2}$ in the small volume of pegmatitic melts relative to cool rocks would be easily diffused into the host rocks and form silicate minerals such as phlogopite, vermiculite and chlorite, while $\mathrm{Al}_{2} \mathrm{O}_{3}$ would be concentrated in the residual melts to form corundum and other Al-rich minerals in pegmatitic veins. The binary diagrams (Fig. 10A, B) indicate that the corundum deposits increase with increasing $\mathrm{MgO}$ and decrease with increasing $\mathrm{SiO}_{2}$, while the binary diagram for $\mathrm{CaO}$ and $\mathrm{SiO}_{2}$ (Fig. 10C) reveals more complex relations. These arise from the addition of $\mathrm{Ca}$ from the host rocks to the residual melt at Vein 1 that became fixed in grossular garnet, whereas scant $\mathrm{Ca}$ input from the host rocks into the residual melt at Vein 2 and greater fractionation of the melt changed the metasomatic process. Moreover, the positive linear correlation between the K/ $\mathrm{Rb}$ ratio and the $\mathrm{K} / \mathrm{Cs}$ ratio (Fig. $12 \mathrm{C}$ ) indicates that $\mathrm{Rb}$ and $\mathrm{Cs}$ inputs are linked to K-bearing minerals 
Fig. 14. Schematic model showing the studied corundum deposits; these are controlled by NNW-SSE (Vein 1) and NNE-SSW (Vein 2) trends, as well as their possible sources and the movement of elements in the metasomatic mineral zones (not to scale). $\mathrm{Si}, \mathrm{K}, \mathrm{Na}$ and $\mathrm{H}_{2} \mathrm{O}$ are diffused from the pegmatitic melt to the host ophiolitic mélange and ultramafic rocks, whereas $\mathrm{Mg}$, Fe and, to a lesser extent, Ca are diffused oppositely, in addition to slight REE and U from ophiolitic mélange rocks. Al-rich pegmatitic melts/fluids will be the clue of corundum formation and other associated minerals as well as common trace elements in the

Vein 1

$\underset{N 8}{\longrightarrow}$ Vein 2

Main minerals: plagioclase, corundum, grossular, phlogopite and muscovite.

Common trace elements: $\mathrm{U}=\mathrm{Th}, \mathrm{Nb}, \mathrm{Zr}$

LREE $<$ HREE

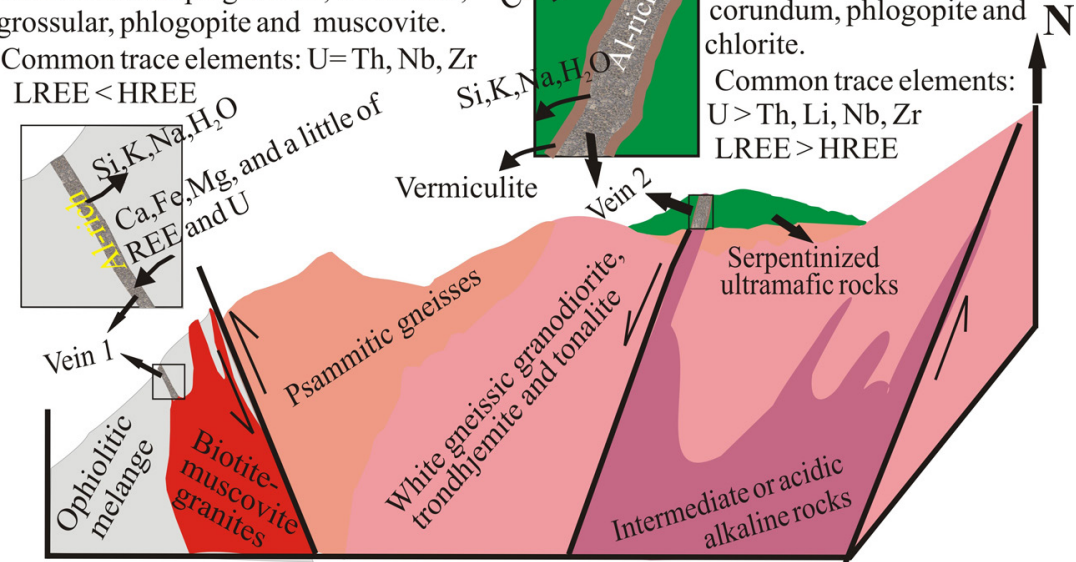

as well as fractionation processes in the melt. The steady Rb levels with increasing Li (Fig. 12D) may have involved uptake of Li into the alteration products (clay minerals) derived from hydrothermal solution activity (e.g., Gurav et al., 2015).

\subsection{Factors controlling emplacement of two veins and their ages}

Our detailed field study and mapping of the Hafafit-Nugrus area indicate that the corundum-bearing pegmatitic veins are structurally controlled by the NNW-SSE fracture for Vein 1 and the NE-SW fracture for Vein 2 (Fig. 2A, C). Additionally, structural studies of the Hafafit-Nugrus area by El Ramly et al. (1984) and Greiling et al. (1984) demonstrated that both psammitic and mafic rocks were more ductile than the acidic gneisses, where the density of fracture distributions is known to depend on the brittle-ductile behaviour of host rocks (e.g. Pollard, 1973). Consequently, the ductile rocks, such as mafic-ultramafic rocks, metasedimentary rocks and psammitic gneisses, are more resistant to fracturing and related veining than acidic granites and gneisses. This factor influences the thickness of the corundum deposit veins in the Hafafit-Nugrus area, where Vein 1 is $20 \mathrm{~cm}$ and Vein 2 is $1 \mathrm{~m}$ in width.

In addition to steep fractures needed for accumulation, segregation of these melts and to facilitate geochemical reactions between adjacent rocks through channelling fluids to form the corundum vein deposits. The upward migration of the melts preceded at faster rates during exhumation, enhancing the formation of these veins of the latest fractionated melts at higher crust level than for earlier melts.
The ages of the corundum deposits can be deduced from field observations. Vein 1 fills a NNWSSE fracture. This fractures trend parallels and is related to the NNW-SSE Nugrus strike-slip fault that formed during an extension stage at 595-575 Ma (Greiling et al., 1994), following continental collision in the late stage of the Pan-African orogeny (e.g. Fritz et al., 2002). The magmas of biotite-muscovite granites were generated during motion of the Nugrus strike-slip fault and migrated upwards along this fault. It evolved to form corundum-bearing pegmatite Vein 1. Consequently, the age of this corundum deposit lies between 595 and 575 Ma. In contrast, the age of corundum deposits in Vein 2 is linked to the age of intermediated and acidic rocks emplaced during Permo-Triassic time, to the Late Cretaceous, as a result of the breakup of Gondwana and the early Central Atlantic opening during this period. Consequently, the reactivation of the Chephren-Kom Ombo arch that led to the emplacement of intermediated and acidic rocks in the Hafafit-Nugrus area along the NE-SW and ENE-WSW trends, which may be represented by extension trends of this arch.

\subsection{Temperature and pressure}

Vein 1 corundum deposits formed from an ascending residual melt of biotite-muscovite granites which solidified at temperatures ranging between 670 and $780^{\circ} \mathrm{C}$ (Abu Elatta \& Mansour, 2019). In comparison, sapphire-bearing leucogranite at Madinat Nugrus to the northeast of Gabal Hafafit formed at $\mathrm{T}$ between 685 and $700^{\circ} \mathrm{C}$ and $0.5 \mathrm{kbar}$ water pressure (Abu Elatta et al., 2013). The Zr con- 
Table 3. Calculated zircon saturation temperatures (in ${ }^{\circ} \mathrm{C}$ )

\begin{tabular}{ccccccccccccc}
\hline Vein & \multicolumn{1}{c}{1} & \multicolumn{1}{c}{2} & \multicolumn{1}{c}{2} \\
\hline Sample no. & 1 & 2 & 3 & 4 & 5 & 6 & 7 & 8 & 9 & 10 & 11 & 12 \\
\hline TZr & 733.6 & 728.9 & 730 & 748 & 798 & 732 & 798 & 817 & 793 & 832 & 817 & 694 \\
\hline
\end{tabular}

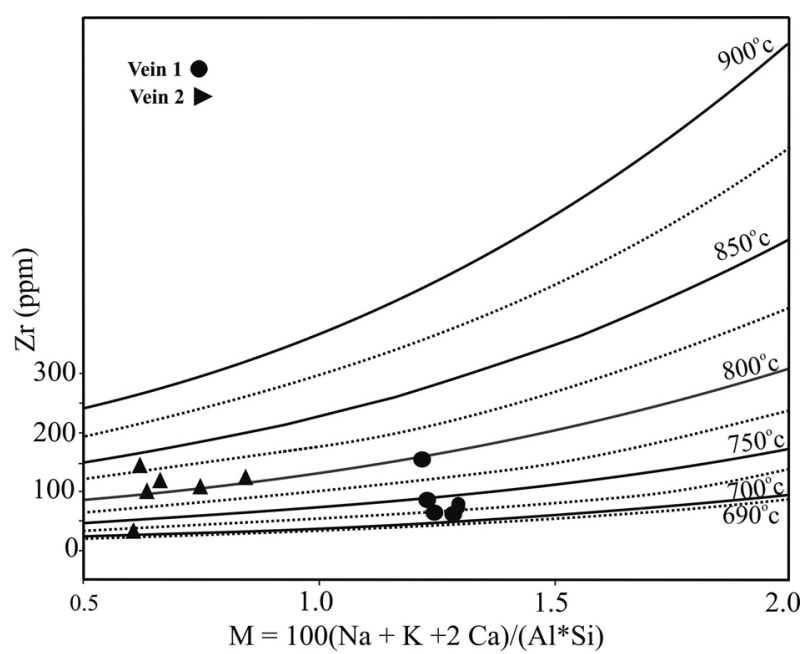

Fig. 15. $\mathrm{Zr}$ (ppm) vs $\mathrm{M}[\mathrm{M}=$ cation ratio $(\mathrm{Na}+\mathrm{K}+2 \mathrm{Ca} /$ $\left.\left(\mathrm{Al}{ }^{*} \mathrm{Si}\right)\right]$ showing the proportion of $\mathrm{Zr}$ that can be dissolved in the two vein melts of various compositions at different temperatures (course of lines by Watson \& Harrison, 1983)

centrations in Vein 1 are used to give the probable temperature formation according to the calculated zircon saturation temperatures (Watson \& Harrison, 983), showing a temperature range from 729 to $798^{\circ} \mathrm{C}$ (Fig. 15; Table 3). The difference between the temperatures of the parent melt of biotite-muscovite granite and its residual melting temperature that formed Vein 1 may be due to latent heat fusion.

Corundum deposit Vein 2 contains euxenite-( $(Y)$ as an accessory mineral. In one of its phases, this mineral is formed at temperatures ranging between 650 and $<800^{\circ} \mathrm{C}$ (Tomasic et al., 2004). Nearly the same result was obtained from the use of calculated zircon saturation temperatures for Vein 2, ranging from 694 to $832^{\circ} \mathrm{C}$ (Fig. 15; Table 3), although Ewing (1974) suggested euxenite-(Y) was crystallised at a T range of 700 to $780^{\circ} \mathrm{C}$. The presence of clinochlore, spinel and talc with the corundum in Vein 2 supports clinochlore breakdown to chlorite-spinel-talc at a temperature of about $720^{\circ} \mathrm{C}$ and $3 \mathrm{kbar}$ water pressure (Cho, 1986).

Consequently, corundum deposits formed in a wide range of temperatures. This wide range of temperatures may be due to the nature and origin of pegmatites. Additionally, corundum deposits of pegmatite bodies formed at higher temperatures than those in the parental pegmatite bodies.

\subsection{High Field Strength elements (HFSE)}

The thorium and uranium anomalies in Vein 1 are due to the evolution of the pegmatitic magma related to fractional crystallisation of biotite-muscovite melts derived from the ophiolitic mélange that consisted mainly of metasedimentary rocks. These parent sources were lixiviated to hydrothermal solutions related to tectonic deformations and emplacement of older granites in the study area, which enriched the residual pegmatitic melt in thorium and uranium. The thorium and uranium anomalies in the corundum-bearing pegmatite Vein 2, however, result from evolved pegmatitic melt derived from the intermediate or acidic melts an alkaline affinity. Such melts emplaced in an intraplate setting are usually enriched in radioactive materials. The positive relation between $U$ and Th (Fig. 11A) in Vein 1, however, is due to the presence of these two elements in the uranothorite. In the case of Vein 2 , these two elements lack any relationship to the post-magmatic process and the nature of pegmatitic melt at this locality. The presence of fractures in the corundum crystals and other minerals of the pegmatitic veins indicate reactivation of the fault along which the vein was formed. Decrease in the Th/U ratio against increasing $\mathrm{SiO}_{2}$ (Fig. 11B) reflects the concentrations of $U$ relative to Th in the residual melts. The residual melt for Vein 1 was enriched by both $U$ and Th, unlike the residual melt for Vein 2 which was only enriched in Th. Enrichment in Th relative to $U$ features in alkaline magmas where some U enters into an aqueous phase as uranyl ions during the final stages of crystallisation of granitic magmas (Attendorn \& Bowen, 1997). However, a U-bearing aqueous phase in this case did not escape from the fracture and remained trapped, increasing the concentration of $U$ relative to Th in the pegmatitic melt. The general decrease in Th with an increasing hybridisation index in residual melts (Fig. 11D) results from fractionation, without input of Th from the host rocks. The weak positive relation between the hybridisation index and $U$ in Vein 1 and a strong negative relation inVein 2 (Fig. 11E) results from addition of $U$ from the host rocks for Vein 1 from metasedimentary rocks of the ophiolitic mélange rocks that are rich in U (Abu Elatta \& Mansour, 2019). The significant relations between REE and the hybridisation index (Fig. 11F) for Vein1 re- 
flects the addition for REE from the host rocks; but with progressive fractionation, REE could become more depleted in the melt. Drastic REE decreases with increasing hybridisation in samples from Vein 2 may mask an early stage of mineralisation rich in REE, but with advance fractionation progressing in melts may become depleted in these elements.

The negative curve linear correction between Ta values and $\mathrm{Ta} / \mathrm{Nb}$ ratios for the samples studied (Fig. 12A) reflects a $\mathrm{Ta} / \mathrm{Nb}$ decrease during differentiation of granitic melts where fractionation leads to a decrease in $\mathrm{TiO}_{2}$ contents (Vlasov, 1966) and any derivative liquid of these melts will show a lower ratio. Consequently, $\mathrm{Nb}$ concentrations and $\mathrm{Nb} / \mathrm{Ti}$ ratios increase, where $\mathrm{Ta}-\mathrm{Nb}$ fractionation can be related to Ti contents in parental source magmas, as both elements are hosted in Ti phases such as rutile, $\mathrm{Nb}$-rich rutile, titanite, perovskite and ilmenite (e.g., Haapala, 1977). A strong positive relationship between $\mathrm{Hf}$ and $\mathrm{Zr} / \mathrm{Hf}$ (Fig. 12B) indicates higher degrees of fractionation in the residual melts. Additionally, Zr and Hf enrichments accompany a predominance of $\mathrm{Cl}$ in these melts (Hildreth, 1979, 1981). Another factor involves preferential mobility of Hf in hydrothermal environments, which tends to increase $\mathrm{Zr}$ / Hf ratio relative to the original compositions during low-temperature alteration (Kosterin et al., 1964).

\section{Conclusions}

Based on a detailed map of the Hafafit-Nugrus area, mineralogical constituents and chemical compositions of the two vein types of corundum-bearing pegmatites, as well as the behaviour of chromophore elements in corundum crystals, several conclusions can be drawn, as follows:

Emplacement of the two types of corundum veins is structurally controlled by the major tectonic events that affected the Hafafit-Nugrus area, whereas the two vein widths are controlled by brittle-ductile behaviour of the host rocks. The ductile host rocks such as mafic-ultramafic rocks and metasedimentary rocks at locality 1 are more resistant to the fracturing and related veining relative to hidden acidic gneisses at locality 2. Accordingly, Vein 1 is $20 \mathrm{~cm}$ and Vein 2 is $1 \mathrm{~m}$ wide.

The studied corundum deposits formed in two periods. The first at about 595 to $575 \mathrm{Ma}$, during the post-Pan-Africa orogeny, and represented by Vein 1-type corundum deposits. The second occurred within the post-Pan-African orogeny, to the Late Cretaceous time, and is represented by Vein 2-type corundum deposits.
The corundum deposits formed by a bimetasomatic process at the contact between the pegmatitic melt and metasedimentary and mafic/ultramafic rocks at locality 1 and ultramafic rocks at locality 2 . This bimetasomatic process took place in oxidising environments, between 729 to $798^{\circ} \mathrm{C}$ and 2 kbar water pressure and between 694 to $832^{\circ} \mathrm{C}$ at Vein 1 and Vein 2 localities, respectively.

The element exchanges took place where fluids, richer in water, $\mathrm{SiO}_{2}$ and alkalies from the pegmatitic melts entered the ophiolitic mélange and ultramafic rocks. This led to the formation of phlogopite, vermiculite, chlorite, clinochlore and talc in the serpentinised ultramafic rocks and ophiolitic mélange rocks.

The Al-rich residual pegmatitic melts formed corundum vein-type deposits and related HFSE minerals. The heterogenetic presence of chromosphere trace elements such as $\mathrm{Fe}, \mathrm{Mg}, \mathrm{Cr}$, and $\mathrm{V}$ produced the coloured corundum in these veins.

The Hafafit-Nugrus area is the only locality on record in the Egyptian basement that contains corundum concentrations. The corundum deposits require a melt source rich in both $\mathrm{Al}$, and $\mathrm{Si}$, which is a justaposition with cool silica-deficient rocks. Similar lithologies and melt conditions may prove suitable for further prospective corundum deposits elsewhere in Egypt and across the globe. The associated anomalies of REE, $\mathrm{Li}, \mathrm{U}$ and Th also have an interest for future investigations in potential sources of these elements in such areas.

\section{References}

Abduriyim, A. \& Kitawaki, H., 2006. Determination of the origin of blue sapphire using Laser Ablation Inductively Coupled Plasma Mass Spectrometry. Journal of Gemology 30, 23-36.

Abu Elatta, S.A., 2007. Occurrence of rare metals deposits at Abu Kruq Area, South Eastern Desert, Egypt. Ain Ahams University, Egypt.

Abu Elatta, S.A. \& Mansour, G.H., 2019. Petrogenesis, geodynamic and radioactivity of the granitic rocks of the Nugrus Weakness Zone, South Eastern Desert, Egypt. Acta Geologica Sinica, in press.

Abu Elatta, S.A. \& Williams-Jones, A.E., 2018. Mineralogy and geochemistry studies on the Nusab El Balgum granitic batches, South Western Desert, Egypt. Arabian Journal of Geosciences 11, 556.

Abu Elatta, S.A., Khaleal, F.M. \& Rashed, M.A., 2013. Characteristic of Madinat Nugrus peraluminous leucogranite carrier of radioactive minerals, Southeastern Desert, Egypt. Research Open Journal of Mineral and Mining Engineering 1, 15-34.

Anders, E. \& Grevesse, N., 1989. Abundance of the elements: Meteoritic and solar. Geochimica et Cosmochimica Acta 53, 197-214. 
Andrew Cowper, L., 1903. Plumasite, an oligoclase corundum rock, near Spanish Peak, California. University of California, Department of Geological Sciences Bulletin 3, 219-229.

Attendorn, H.G. \& Bowen, R.N.C., 1997. Radioactive and stable isotope geology. Chapman \& Hall, London, 87 pp.

Ballouard, C., Poujol, M., Boulvais, P., Branquet, P., Tartèse, R. \& Vigneresse, J.L., 2016. Nb-Ta fractionation in peraluminous granites: a marker of the magmatic-hydrothermal transition. Geology 44, 231-234.

Boynton, W.V., 1984. Geochemistry of the rare earth elements: meteorite studies. In: Henderson, P. (Ed.), Rare Earth Element Geochemistry. Elsevier, 63-114.

Bucher, K., Capitani, C. De. \& Grapes, R., 2005. The development of a margarite-corundum blackwall by metasomatic alteration of a slice of mica schist in ultramafic rock, Kvesjöen, Norwegian Caledonides. The Canadian Mineralogist 43, 129-156.

Černý, P., Meintzer, R.E. \& Anderson, A.I., 1985. Extreme fractionation in rare-element granitic pegmatites: Selected samples of data and mechanism. The Canadian Mineralogist 23, 381-421.

Cho, M., 1986. A kinetic study of clinochlore and its high temperature equivalent forsterite+cordierite-spinel at 2 kbar water pressure. American Mineralogist 71, 68-77.

El Ramly, M.F. \& Greiling, R., 1988. Wadi Hafafit Area 1:100,000 Geological Map. Technische Fachhochschule, Berlin.

El Ramly, M.F., Greiling, R.O., Kroner, A.\& Rashwan, A.A., 1984. On the tectonic evolution of Wadi Hafafit area and environs, Eastern Desert of Egypt. [In:] Proceedings of symposium on the Pan-African crustal evolution in the Arabian Shield, 113-126.

El Ramly, M.F., Greiling, R.O., Rashwan, A.A. \& Rasmy, A.H., 1993. Explanatory note to accompany the geological and structural maps of Wadi Hafafit area, Eastern Desert of Egypt. Geological Survey of Egypt Paper 68.

El Sayed, R.M, Assran, H.M. \& Abu Elatta S.A., 2014. Petrographic, radiometric and paleomagnetic studies for some alkaline rocks, south Nusab El Balgum mass complex, south Western Desert, Egypt. Geomaterials 4, 27-4.

Engel, A.E., Dixon, T.H. \& Stern, R.J., 1980. Late Precambrian evolution of Afro-Arabian crust from ocean arc to craton. Bulletin of the Geological Society of America 91, 699-706.

Erlank, A.J., Marchant, J.W., Cardoso, M.P. \& Ahrens, L.H., 1978. Zirconium. [In:] K.H. Wedepohl (Ed.): Handbook of Geochemistry. Springer, Part II, 40 pp.

Ewing, R.C., 1974. Mineralogy of metamict rare earth $\mathrm{AB}_{2} \mathrm{O}_{6}$-types Niobium-Tanalum-Titanium oxides. Stanford University, California, $45 \mathrm{pp}$.

Fritz, H., Dallmeyer., D.R., Wallbrecher, E., Loizenbauer, J., Hoinkes, G., Neumayr, P. \& Khudeir, A.A., 2002, Neoproterozoic tectonothermal evolution of the Central Eastern Desert, Egypt: a slow velocity tectonic process of core complex exhumation. Journal of African Earth Sciences 34, 137-155.
Green, T.H., 1995. Significance of $\mathrm{Nb} / \mathrm{Ta}$ as an indicator of geochemical processes in the crust-mantle system. Chemical Geology 120, 347-359.

Greiling, R.O., Abdeen, M.M., Dardir., A.A., El-Akhal, H., El-Ramly, M.F., Kamal El-Din G.M., Osman, A.F., Rashwan, A.A., Rice, A.H.N. \& Sadek, M.F., 1994. A structural synthesis of the Proterozoic Arabian-Nubian Shield in Egypt. Geologische Rundschau 83, 484-501.

Greiling, R., Kroner, A. \& El Ramly, M.F., 1984. Structural interference patterns and their origin in the Pan-African basement of the southeastern Desert of Egypt. [In:] A. Kröner \& R. Greiling (Eds): Precambrian Tectonics Illustrated. Schweizerbart, Stuttgart, 40-412 pp.

Greiling, R., Kroner, A., El Ramly, M.F., El Akhal, H. \& Stern, R.J., 1988. The tectonic evolution of the northwestern Red Sea margin as related to basement structure. Tectonophysics 153, 179-191.

Gurav, T., Chandrasekharam, D. \& Singh, H.K., 2015. Trace Element and REE concentrations in the thermal waters, West Coast Geothermal Province, India. Proceedings World Geothermal Congress, Melbourne, 1-9.

Haapala, I., 1977. Petrography and geochemistry of the Eurajoki stock, a rapakivi-granite complex with greisen-type mineralization in southwestern Finland. Bulletin Geological Survey of Finland 286, 128 pp.

Hildreth, W., 1979. The Bishop Tuff: Evidence for the origin of compositional zonation in silicic magma chambers. Geological Society of America Special Paper 180, 43-74.

Hildreth, W., 1981. Gradients in silicic magma chamber: Implication for lithospheric magmatism. Journal of Geophysical Research 86, 10153-10192.

Irber, W., 1999. The lanthanide tetrad effect and its correlation with $\mathrm{K} / \mathrm{Rb}, \mathrm{Eu} / \mathrm{Eu}^{*}, \mathrm{Sr} / \mathrm{Eu}, \mathrm{Y} / \mathrm{Ho}$ and $\mathrm{Zr} / \mathrm{Hf}$ of evolving peraluminous granite suites. Geochimica et Cosmochimica Acta 63, 489-508.

Issawi, B., Francis, M., Youssef, A. \& Osman, R., 2009: The Phanerozoic of Egypt: a geodynamic approach. Geological Survey of Egypt Special Publication 81, 589 pp.

Kosterin, A.V., Shevaleyevskii, I.D. \& Kizyura, V.E., 1964. Behaviour of zirconium and hafnium in the pegmatites of the Kuramin Mountain Range. Geochemistry International 1, 989-993.

Lentz, D., 1996. U, Mo, REE mineralization in late tectonic granitic pegmatites, southwestern Grenville Province. Ore Geology Reviews 11, 197-227.

Linnen, R.L. \& Keppler, H., 2002. Melt composition control of $\mathrm{Zr} / \mathrm{Hf}$ fractionation in magmatic processes. Geochimica et Cosmochimica Acta 66, 3293-330.

Moghazi, A.M., Hassanein, M.A., Mohamed, F.H. \& Ali, S., 2004. Late Neoproterozoic strongly peraluminous leucogranites, south Eastern Desert, Egypt. Petrogenesis and geodynamic significance. Mineralogy and Petrology 81, 19-41.

Peucat, J.J., Ruffault, P., Fritsch, E., Bouhnik-Le Coz, M., Simonet, C. \& Lasnier, B., 2007. Ga/Mg ratios as a new geochemical tool to differentiate magmatic from metamorphic blue sapphires. Lithos 98, 261-274.

Pirajno, F., 1992. Hydrothermal mineral deposits. Principles and fundamental concepts for the exploration geologist. Springer-Verlag. Berlin, 1-155. 
Pollard, D.D., 1973. Derivation and evaluation of a mechanical model for sheet intrusions. Tectonophysics 19, 233-269.

Rankin, A.H., Greenwood, J. \& Hargreaves, D., 2003. Chemical fingerprinting of some East African gem rubies by Laser Ablation ICP-MS. Journal of Gemmology $28,473-481$.

Rudnick, R.L. \& Fountain, D.M., 1995. Nature and composition of the continental crust: a lower crustal perspective. Reviews of Geophysics 33, 267-309.

Saminpanya, S., Manning, D. \& Henderson, D., 2003. Trace elements in Thai gem corundums. Journal of Gemmology 28, 392-398.

Serencsists, C.M.C., Faul, H., Foland, K.A., El-Ramly, M.C. \& Hussein, A.A., 1979. Alkaline ring complexes in Egypt: Their ages and relationship to tectonic development of the Red Sea. Annals of Geological Survey of Egypt 9, 102-116.

Serotta, A. \& Carò, F., 2014. Evidence for the use of corundum abrasive in Egypt from the Great Aten Temple at Amarna. Horizon 14, 2-4.

Stoeser, D.B. \& Camp, V.E., 1985. Pan-African microplate accretion of the Arabian Shield. Bulletin of Geological Society of America 96, 817-826.

Taylor, S.R. \& McLennan, S.M., 1985. The continental crust: Its composition and evolution. Oxford, Blackwell, $312 \mathrm{pp}$.

Tomasic, N., Wang-Gajovic, A., Bermanec, V. \& Rajic, M., 2004. Recrystallization of metamict $\mathrm{Nb}-\mathrm{Ta}$-Ti-REE complex oxides: A coupled X-ray-diffraction and Raman spectroscopy. The Canadian Mneralogist 42, 1847-1857.
Voudouris, P., Mavrogonatos, C. , Graham, I., Giuliani, G., Melfosm, V., Karampelas, V, Karantoni, V. Wang, K., Tarantola, A., Zaw, K., Meffre, S., Klemme, S., Berndt, J., Heidrich, S., Zaccarini, F., Fallick, A., Tsortanidis, M. \& Lampridis, A., 2019. Gem corundum deposits of Greece: Geology, mineralogy and genesis. Minerals 9, 49-50.

Vlasov, K.A., 1966. Geochemistry and mineralogy of rare elements and genetic types of their deposits. I. Geochemistry of rare elements. Israel Program for Scientific Translations, Jerusalem, 688 pp.

Wang, L. \& Liang, T., 2015. Geochemical fractions of rare earth elements in soil around a mine Tailing in Baotou, China. Scientific Reports, 5, https://doi.org/10.1038/12483.

Watson, E. \& Harrison, T.M., 1983. Zircon saturation revisited: temperature and composition effects in a variety of crustal magma types. Earth and Planetary Science Letters 64, 295-304.

Weyer, S., Musker, C., Rehkämper, M. \& Mezger, K., 2002. Determination of ultra-low Nb, Ta, Zr and Hf concentrations and the chondritic $\mathrm{Zr} / \mathrm{Hf}$ and $\mathrm{Nb} / \mathrm{Ta}$ ratios by isotope dilution analyses with multiple collector CP-MS. Chemical Geology 187, 295-313.

Zharikov, V., Pertsev, N., Rusinov, V., Callegari, E. \& Fettes, D., 2007. Metasomatism and metasomatic rocks. [In:] Fettes, D. \& Desmons, J. (Eds): Metamorphic Rocks: A Classification and Glossary of Terms. Cambridge University Press, Cambridge, 58-68 pp.

Manuscript received: 6 July 2020 Revision accepted: 3 October 2020 